\title{
HAITIAN BOAT PEOPLE: A STUDY IN THE CONFLICTING FORCES SHAPING U.S. IMMIGRATION POLICY
}

\author{
AleX STEPICK*
}

I

\section{InTRODUCTION: A CASE STUDY}

Since the Haitian boat people began arriving in southern Florida in 1972,' the U.S. Government has been engaged in a ceaseless struggle to expeditiously return as many as possible to Haiti. The following story is a composite of different experiences of those boat people. It reflects the reasons they have come and the disputes surrounding both their presence in the United States and their claims for political asylum. ${ }^{2}$

My name is Jean and I came to the United States in 1978 to find freedom and to work. ${ }^{3}$

Well what happened to me was it was a Macoute that came to rent a bicycle from me for one dollar.

When I look around, I didn't see him. I never saw him at all. I looked for him all over the place. I found him standing somewhere leaning on the bicycle. I went in and told him, "How come you didn't bring the bicycle back to me?"

He told me, "Don't you know that I bought it from you for a dollar?"

I thought he was kidding. I held the bicycle and took it away from him. Right away he hit me with a club. He had already hit me.

After that, when I was trying to see if I could get away, four more came and started beating on me. They started beating on me. They break my head over here too.

I ran. I went. I ran and hid in the woods. While I was hiding in the woods, one of my cousins knew where I was hiding. He came and told me they had taken one of my brothers. He said they were pressuring him to tell them where I was hiding. When he couldn't tell them where I was, they took him to a public place in front of everybody and they killed him.

I spent another two or three months, and the way I left, the reason I left the place was, I

* Assistant Professor, Department of Sociology and Anthropology, Florida International University. Numerous individuals have provided me with invaluable assistance. I would especially like to thank: Congressman Mickey Leland, Mike Hudson, Rick Swartz, Ira Kurzban, Virginia Dominiguez, Barry Levine, Michael Hooper, and Tony Maingot. I, of course, remain responsible for any errors, omissions, or misinterpretations.

1. F. Ficklen, Haitians in New York, Some Notes and Observations 18 (April 1980) (paper presented to the Applied Anthropology Colloquium, Columbia University).

2. Traditionally "refugee" refers to individuals outside the country seeking admission. "Asylum" refers to the status extended to individuals within the country, seeking refugee status. This paper maintains the same distinction.

3. This story is an amalgamation of affidavits of Haitian refugees who testified in Haitian Refugee Center v. Civiletti, 503 F. Supp. 442 (S.D. Fla. 1980), modifred sub nom. Haitian Refugee Center v. Smith, 676 F.2d 1023 (5th Cir. 1982), including especially the case of Odilius Jean. Parts were also derived from Petro, What Did the Haitians Do?, St. Petersburg Times, Nov. 11, 1979, at 8, and Keldan, Tales of the Tonton Macoutes from Haitians Who Fled, Philadelphia Inquirer, Oct. 8, 1979, at Al. 
had another little brother. My cousin came and told me they held him and cut his throat with a knife, but he did not die.

I went to the Northwest to find a boat to go to Miami. Finding a boat wasn't hard, but I did have to borrow the $\$ 1,500$ for passage. I sold one of my small plots to a local gros negre $^{4}$ who buys from anyone needing money to go to Miami. The price wasn't too good and we had the land in the family since the time of Dessalines, but I couldn't stay in the mountains forever. Anyway, I thought, once in Miami I could earn enough to buy it back and probably even some more. Other families in the village received as much as $\$ 200$ a month from relatives in Miami. That's more than most could earn in three years.

The boat left Haiti at the end of August 1978. In the beginning there were 145 of us crammed into a twenty foot, leaky, wooden sailboat. Not everyone could even sit down at the same time.

Their destination was 720 miles away, but Jean had little idea how long it would take to get there. The captain said it would depend on the winds and luck. They apparently had little of either. They ran out of water first, and then food. Many tried to drink the sea water, but it made Jean sick; he preferred to go thirsty. They began to die, and after two weeks there were barely more than 100 still alive. Although Jean did not know it, they had gone about 600 miles and were still 120 miles south of Miami.

One evening a U.S. Coast Guard cutter approached them. Jean and the others felt joy and relief. "We're saved," he thought. Jean, along with everyone else, crowded on the side of the boat closest to the cutter. Some began jumping into the water and swimming towards the cutter. The sailboat tilted and then capsized. Jean did not know how to swim and he thrashed around in panic. Three drowned before the Coast Guard saved the rest.

When they arrived in Miami, they were greeted by Immigration and Naturalization Service (INS) authorities, who transported them to an INS processing center. The center was already filled with other Haitians awaiting the U.S. Government's decision whether to allow them to stay in the United States or to return them to Haiti.

Through an interpreter, Jean told an INS official his story of the bicycle, the Macoute, and why he left Haiti. The INS officer said that Jean did not qualify for political asylum, that he was coming to the United States to work, that he left Haiti because of a personal dispute, and that if he stayed in the United States he would remain in jail. The INS officer told Jean that he could fly back to Haiti for free if he would just sign a piece of paper. Jean knew that others had signed the paper and disappeared, and he knew he did not want to go back to Haiti, where he believed he would meet certain death. Besides, some of the others in the camp said there was still a chance they could be released.

Jean's dilemma mirrors the plight of these refugees under current American policy perspectives. The Government contends that, while a few of the Haitians deserve asylum, the vast majority are economic - not political-refugees. They are not fleeing political persecution, but are attracted to the vastly superior economic opportunities in the United States. As such, they do not have a legitimate legal claim to remain in the United States. However, if they were fleeing political perse-

4. Gros negre is a Creole phrase which translates literally as "big black." It is generally used to refer to an individual in a local rural area who is slightly better off than his neighbors, or a "big shot." 
cution, the United States would be obligated under international and domestic law to protect them from further persecution. The Government has dismissed as "frivolous" all but a hundred of the Haitian claims for political asylum. ${ }^{5}$ Stories such as Jean's are discounted as "personal disputes" or fabrications frequently encouraged by Haitian advocacy lawyers in the United States. In addition, many argue that allowing the mass of the boat people to remain in the United States would establish a precedent which would make it impossible to deny access to other "economic refugees," such as those from Mexico and other parts of Latin America and the Caribbean.

Haitian refugee advocates assert the contrary: The boat people are fleeing the pervasive and extreme political persecution of Duvalier-ruled Haiti. The Haitian advocates claim that the U.S. Government's consistent denials of full, fair hearings for the Haitian boat people are racist (since the Haitians are black), ideologically biased (since they are fleeing a friendly, rightwing dictatorship), and illegal under international and U.S. law (since the United States has a nondiscriminatory, binding commitment to protect refugees from persecution). At a minimum, according to these advocates, the Haitians deserve a full and fair hearing of their claims for political asylum. ${ }^{6}$

Do the Haitians have a valid claim for remaining in the United States? Would their acceptance further open the floodgates to Third World masses fleeing authoritarian regimes? Has the INS trammeled their rights as asylum applicants, or are the vast majority of their claims as frivolous as the INS asserts?

The answers to these questions turn on the definition, as established by international and U.S. law, of refugees, their rights, U.S. obligations toward them, and conditions in their homelands. A review of these topics indicates that there is some truth to both sides of the argument; Haitians are both economic and political refugees. The conceptual framework embodied in international and U.S. law does not adequately categorize individuals fleeing a regime which exacerbates poverty and exploits the common man while efficiently and viciously repressing the slightest real or imagined criticism. Foreign policy concerns about other Third World migrants lead the U.S. Government to emphasize the boat people's economic motivations. On the other hand, humanitarian considerations and concern for human rights and economic development in Haiti lead Haitian advocates to emphasize the political motivations of the boat peoples' departures, especially the likelihood of persecution if they are returned.

THE LAW

An examination of the definition and rights of the refugee within international and U.S. law reveals ambiguities which have allowed the United States to con-

5. Caribbean Migration: Oversight Hearings Before the Subcomm. on Immigration, Refugees and Int' Law of the House Comm. on the Judiciary, 96th Cong., 2d Sess. 152 (1980) (prepared statement of Rep. Shirley Chisholm).

6. Id. at 138, 154, 174-75 (statements of Elizabeth Holtzman, Subcomm. Chairman; Rep. Shirley Chisholm; and Nancy Nicalo, Director, Immigration and Refugee Program, Church World Service). 
struct a refugee policy favoring those fleeing leftist totalitarian regimes, while discriminating against those fleeing rightist authoritarian regimes.

\section{A. International Law}

Persecution and flight from persecution have been with man as long as civilization has existed. Until this century, little attention was given, either in law or in sentiment, to the plight of refugees. However, the massive movements caused by this century's revolutions and wars, and the increasing interdependence of the world's economic and political systems have produced an awareness of the problems of refugees.

While Latin American law and some extradition treaties have recognized the peculiar status of refugees for some time, ${ }^{7}$ it was not until after World War II that the developed countries and the international community in general began to construct mechanisms for controlling and alleviating the refugee crises. ${ }^{8}$

In drafting the 1948 Universal Declaration of Human Rights, ${ }^{9}$ some nations proposed a provision guaranteeing every individual a right to asylum, or "droit d'asylee."10 The proposal was defeated, however, on the grounds that it contravened the fundamental principle of territorial sovereignty which gives a state the right to bar aliens from entry into that state. ${ }^{11}$

The debate illustrates a basic conflict of refugee policy in international law: Individuals have rights in their own countries; when those rights are abrogated, individuals have a "right" to flee and be protected from persecution, but states in which they may seek asylum also have the right to deny them entry. ${ }^{12}$

The Universal Declaration of Human Rights skirted the issue by stating in its final text that "everyone has the right to seek and to enjoy in other countries asylum from persecution."13 The right to "enjoy asylum," however, was limited to the right of every state to offer refuge and to resist demands for extradition. ${ }^{14}$

The issue was confronted more directly in the United Nations' 1951 Convention on the Status of Refugees and the subsequent 1967 Protocol Relating to the Status of Refugees, which extended the protections adopted in the Convention to a broader group of aliens. ${ }^{15}$

7. Comment, Territorial Asylum in the Americas: Practical Considerations for Relocation, 12 LAW AM. 359 (1980).

8. Dirks, The Plight of the Homeless: the Refugee Phenomena, BeHind the Headlines, Aug. 1980, at 1.

9. G.A. Res. 217A, U.N. Doc. A/810 (1948).

10. Comment, The Dilemma of the Sea Refugee: Rescue without Refuge, 18 HarV. INT'L L.J. 577,586 (1977).

11. Id. See also Weis, The United Nations Declaration on Territorial Asylum, 1969 CAN. Y.B. INT'L LAW 92, 94-97.

12. Weis, supra note 11, at 117. See also Plender, Admission of Refugees: Draft Convention on Territorial Asylum, 15 SAN Diego L. Rev. 45 (1977).

13. G.A. Res. $217 \mathrm{~A}$, supra note 9 , at art. 14.

14. The development of this article is discussed in Comment, supra note 10.

15. Convention Relating to the Status of Refugees, July 28, 1951, 189 U.N.T.S. 150, reprinted at 19 U.S.T. 6259 [hereinafter cited as Convention]; Protocol Relating to the Status of Refugees, Jan. 31, 1967, 19 U.S.T. 6223, T.I.A.S. No. 6557, 606 U.N.T.S. 267 (effective Nov. 1, 1968) [hereinafter cited as Protocol]. The United States has ratified the Protocol, which incorporates almost all of the terms of the Convention. 
Article 1 of the UN Protocol provides the most widely accepted definition of a refugee: $A$ refugee is a person who

owing to well-founded fear of being persecuted for reasons of race, religion, nationality, membership of a particular social group or political opinion, is outside the country of his nationality and is unable or, owing to such fear, is unwilling to avail himself of the protection of that country; or who, not having a nationality and being outside the country of his former habitual residence is unable or, owing to such fear, is unwilling to return to it."16

Articles 31, 32, and 33 of the Convention further define the rights of refugees with respect to state sovereignty. Article 31 restrains states from imposing penalties

on account of their illegal entry or presence, on refugees who, coming directly from a territory where their life or freedom was threatened in the sense of Article 1, enter or are present in their territory without authorization, provided they present themselves without delay to the authorities and show good cause for their illegal entry or presence. ${ }^{17}$

Article 32 prohibits states from expelling "a refugee lawfully in their territory save on grounds of national security or public order," and then "only in pursuance of a decision reached in accordance with due process of law;" and finally, "[t]he Contracting States shall allow such a refugee a reasonable period within which to seek legal admission into another country." 18

Article 33 articulates the principle of non-refoulement: "No Contracting State shall expel or return ("refouler") a refugee in any manner whatsoever to the frontiers of territories where his life or freedom would be threatened on account of his race, religion, nationality, membership of a particular social group or political opinion."19

The UN Convention and Protocol thus protect a refugee by prohibiting contracting states from expelling anyone to territories where he would be subject to persecution. The Protocol also maintains the principle of state sovereignty over immigration by not compelling states to accept refugees into their territories. These protections apply only to those immigrants who are indeed refugees, i.e., individuals who have a "well-founded fear of persecution." Neither the UN documents nor any other international instruments, however, provide a precise definition of a "well-founded fear of persecution."

The British have tended to define persecution rather narrowly. In one case, the British Immigration Appeals Tribunal stated that an individual prosecuted for breaching a country's law had not necessarily been persecuted even though the laws in question were clearly political. Those laws had imposed penalties for degrading or scoffing at the state, its system or its public organs, for extolling fascism, and for disseminating false information injurious to the state. ${ }^{20}$

At the other extreme, it has been argued that persecution may include actions by the general public against religious, ethnic, or political groups which pose no immediate threat to life or limb but which may produce a state of mind making it

16. Convention, supra note 15, at art. 1 (as amended by Protocol, supra note 15, at art. 1).

17. Id. art. 31 .

18. Id. art. 32 .

19. Id. art. 33 .

20. Plender, supra note 12 , at 53-54. 
intolerable to remain in that country. ${ }^{21}$ Although no country has implemented law or policy quite so broad, some European countries did confront a similar situation in the mid-1960's when a growing number of persons from Eastern Europe fled to western European countries. The prevailing opinion in the recipient countries was that the majority of the refugees were fleeing both the generalized political repression and the relative economic deprivation of the Communist countries. In the recipient countries' interpretations, the refugees did not strictly fit the UN definition. Nevertheless, it was considered impolitic and inhumanitarian to return them, especially because the refugees argued that they could be persecuted upon returning simply for having fled. The Scandinavian countries, followed by the Netherlands, introduced the concept of "B-status refugee" in legal and administrative practice. B-status refugees were allowed to remain, yet were distinguished from those persons fleeing individualized persecution. ${ }^{22}$

The United States has not created such an intermediate status, but historically its practice has been to grant a blanket presumption of persecution to those fleeing Communist states, while maintaining a far stricter standard for those fleeing rightist authoritarian regimes. This dichotomous policy and the inherent tension between this policy and the general humanitarian principles of the UN Protocol is one of the underlying issues in the controversy involving the Haitian boat people.

\section{B. U.S. Law and Policy Toward Refugees}

Give me your tired, your poor, your huddled masses yearning to breathe free.

The Statue of Liberty, bearing the quoted humanitarian words of welcome, was unveiled in 1886. Ironically, the unveiling came shortly after the passage of the Chinese Exclusion Act, America's first restrictive immigration law. ${ }^{23}$ Since the Exclusion Act, American immigration has been highly selective: race and national origin were important criteria in the formulation of U.S. immigration policy, at least until the passage of the Immigration and Nationality Act (INA) in $1952 ;{ }^{24}$ with regard to refugees, foreign policy considerations have predominated. ${ }^{25}$

The end of World War II and the emergence of the Cold War were the two major catalysts in the formation of U.S. and international refugee law. ${ }^{26}$ At the end of the war the Allied armies found themselves guardians of $8,000,000$ people,

21. Dirks, supra note 8 , at $2-3$.

22. Suhrke, Global Refugee Movements and Srategies of Response, in U.S. IMMIGRATION AND REFUGEE POLICY 157 (M. Kritz ed. 1983).

23. The U.S. Congress passed the first Chinese Exclusion Act, ch, 126, 22 Stat. 58 (reptaled 1943), in 1882. Chinese laborers were banned from entering for ten years, although some merchants and scholars were granted temporary visas. See M. Kingston, China Men (1980) (a detailed discussion of U.S. immigration law vis-a-vis the Chinese). See also Evans, The Political Refugee in United States Immigration Law and Practice, 3 INT'L LAW. 204 (1969) (a discussion of the history of general asylum law and policy).

24. Ch. 477, 66 Stat. 163 (codified as amended at 8 U.S.C. $\$ \$ 1101-1546$ (1976 \& Supp. 1981)).

25. In 1933, Congress passed what may be called the first refugee act when it enabled White Russian emigres to legalize their stay in the United States if they could prove entry before July 1, 1933 and were bona fide refugees of good moral character. Ch. 429, 48 Stat. 429 (1934) (repealed 1940). See Schroeder, Refugee Policy, 1 Editorial Research REP. 387, 396 (1980).

26. See Schroeder, supra note 25; Roberts, The U.S. and Refugees: The Refugee Act of 1980, 1981 WORLD Refugee SuRvey 45, 45-46 (1981). 
including survivors of extermination camps, prisoners of war, forced laborers from states conquered by Germany, and thousands who fled before the advance of the Russian Army. Many of these people refused to return to their homes behind the Iron Curtain for fear of persecution. The British, French, and American Governments refused to accede to Soviet demands for forced repatriation. ${ }^{27}$

A series of ad hoc U.S. refugee programs followed. Most legislation commenced with broad humanitarian language offering protection to those who faced "persecution or fear of persecution on account of race, religion or political opinions." However, the applicability of such legislation was, in fact, generally limited to "freedom fighters" who were voting with their feet by fleeing communism. ${ }^{28}$

In 1952, Congress passed the INA, popularly known as the McCarran-Walter Act, which remains the law governing immigration into the United States. ${ }^{29}$ The INA was a somewhat revised codification of the immigration laws then in effect. It was not designed to encourage an influx of aliens and contained no specific provisions for refugees. ${ }^{30}$ Rather, refugees were viewed as a temporary, nonrecurring phenomenon to be accommodated by later measures such as the Refugee Relief Act of $1953 .^{31}$

The INA included two provisions which were to become the primary mechanisms for admitting future refugee groups into the United States: (1) the withholding of an alien's deportation; ${ }^{32}$ and (2) the administrative parole of aliens into the United States. ${ }^{33}$ Which of these provisions would be utilized depended upon whether an alien had already entered the United States, legally or illegally, or whether he was applying for admission at the frontier.

Section 243(h) of the INA authorizes the Attorney General to withhold deportation of an alien when, in the opinion of the Attorney General, the alien would be subject to physical persecution. ${ }^{34}$ In 1965, the provision was amended by deleting the physical persecution requirement and replacing it with the phrase "persecution on account of race, religion or political opinion."35 Nevertheless, the provision emphasizes the discretionary power of the Attorney General and places the burden of proof on the alien. ${ }^{36}$ Furthermore the provisions of section 243(h) are only available to aliens who have effected entry and are undergoing deportation

27. P. Glist, History of the Seventh Preference (1980) (unpublished manuscript available at the law firm of Hogan and Hartson, Washington, D.C.).

28. Id. at 20. See Evans, supra note 23, at 217-21; Schroeder, supra note 25, at 396-399; see also Speer, America's Post-War Refugee Measures: A Sketch of Executive and Legislative Action, 4 INr'L LAW. 709 (1970). All offer summaries of the U.S. post-World War II refugee programs.

29. Ch. 477, 66 Stat. 163.

30. Evans, supra note 23 , at 215.

31. Ch. 336, 67 Stat. 400 .

32. Section 243(h), 66 Stat. at 214 (codified as amended at 8 U.S.C. $\S 1253(\mathrm{~h})$ (Supp. 1981)).

33. Section 212(d)(5), 66b Stat. at 188 (codified as amended at 8 U.S.C. $\$ 1182$ (d)(5) (Supp. 1981)).

34. Section $243(\mathrm{~h}), 66$ Stat. at 214.

35. Act of Oct. 3, 1965, Pub. L. No. 89-236, § 11 (f), 79 Stat. 911,918 (codified as amended at 8 U.S.C. $\S 1253$ (h) (Supp. 1981)). There has been considerable writing on this point. See Evans, supra note 23, at 221; Frank, Effect of the 1967 United Nations Protocol on the Status of Refugees in the United States, 11 INT'L LAW. 291, 293 (1977).

36. Frank, supra note 35, at 301. See also Note, The Right of Asylum Under United States Law, 80 COLUM. L. REV. 1125, 1137 (1980); Note, Coriolan v. Immigration and Naturalization Service: A Closer Look at Immigration Law and the Political Refugee, 6 SyracuSE J. INT'L L. \& CoM. 133, 138 (1978). 
proceedings. ${ }^{37}$ Aliens apprehended before effecting entry, perhaps in territorial waters or at a port of entry, have their cases heard in exclusion proceedings for which section $243(\mathrm{~h})$ claims are not allowed. ${ }^{38}$

The INA also authorizes the Attorney General, "in his discretion," to temporarily parole any alien into the country for "emergent reasons or for reasons deemed strictly in the public interest." 39 Although Congress envisioned this authority as applying in only limited circumstances and numbers, ${ }^{40}$ more refugees have been admitted under the parole authority than by any other mechanism. ${ }^{41}$ Because of the virtually continuous defections from Eastern Europe after the Hungarian revolt of 1956, the Attorney General began to rely extensively on the parole authority. ${ }^{42}$ In 1965 Congress attempted to restrict the use of parole by adding a "seventh preference" for refugees who were defined as those fleeing Communist countries in the Eastern Hemisphere or certain countries of the Middle East. ${ }^{43}$ Yet when the Cuban airlift program began the following year, the seventh preference proved to be too narrow still, for the Attorney General again invoked the parole authority for massive numbers of refugees. ${ }^{44}$

In 1968 the United States became a signatory to the 1967 UN Protocol Relating to the Status of Refugees. ${ }^{45}$ The Protocol included no bias in favor of those fleeing communism. To the contrary, the language clearly carried no ideological biases. Technically, the Protocol superseded U.S. refugee law and thus should have eliminated the bias in U.S. law. This did not prove to be the case, however. In the Senate hearings on the treaty, the executive branch testified that the Protocol resulted in no significant changes in U.S. laws, and no laws or regulations were implemented to carry out the new provisions. ${ }^{46}$

\section{Asylum Provisions}

The law pertaining to asylum was intended primarily for individuals applying for entry into the United States as refugees from abroad. Aside from section 243(h), which allowed the Attorney General to withhold deportation, little atten-

37. 8 U.S.C. $\S 1253$ (h) (Supp. 1981).

38. See Evans, supra note 23 , at 225 for a discussion of the different procedures.

39. 8 U.S.C. \& $1182(d)(5)$ (Supp. 1981).

40. Schroeder, supra note 25 , at 399.

41. Roberts, supra note 26, at 46. See also Schroeder, supra note 25, at 393; Note, Behind the Paper Curtain: Asylum Policy versus Asylum Practice, 7 N.Y.U. REv. L. \& SoC. Chance 107, 127 (1978). The parole authority was first introduced into U.S. law in the Immigration Act of 1917, ch. 29, 39 Stat. 874 (repealed 1952). The act also exempted from exclusion victims of religious or political persecution. Id. at $\S 3$.

42. Roberts, supra note 26 , at $45-46$.

43. Act of Oct. 3, 1965, Pub. L. No. 89-236, $\S 3,79$ Stat. 911,912 (amending $\S 203$ of INA, 66 Stat. at 175, 8 U.S.C. $\$ 1153$ (1976 \& Supp. 1981)). P. Glist, supra note 27, offers an excellent summary of the seventh preference's history. The work specifically examines the peculiar circumstances which prompted the inclusion of certain countries of the Middle East along with Communist nations. See also Roberts, supro note 26 , at 46 .

44. Roberts, supra note 26 , at 46.

45. Protocol, supra note 15.

46. Frank, supra note 35, at 296. See also SUbCOM. ON IMMIGRATION, CrTIZeNSHIP, AND INT'L LAW, House Comm. on the Judiciary, 94th Cong., 2d Sess., Hattian Emigration 2 (Comm. Print 1976) [hereinafter cited as SUBCOMMITTEE REPORT]; Pierre v. United States, 547 F.2d 1281, 1288 (5th Cir.) vacaled and remanded for consideration of mootness, 434 U.S. 962 (1977). 
tion was paid to those who applied at U.S. borders. In 1970, however, after a Lithuanian seaman seeking asylum in the United States was forcibly returned to a Soviet vessel, the Secretary of State ordered that full consideration be given to all asylum requests, whether made abroad or in the United States. ${ }^{47}$ The order invoked the Protocol as the standard and impetus for the regulations. The 1972 order and 1974 regulations ${ }^{48}$ defined who could apply for asylum and the structure of adjudication. Applications for asylum were to be made to the INS District Director who could "approve or deny the application in the excercise of discretion." 49 The decision was to be made in writing, and was not subject to appeal, except that claims under the Protocol could be reinitiated at subsequent "expulsion hearings." 50 The Attorney General interpreted this exception to apply to deportable aliens only, and not those in exclusion proceedings. Those in deportation proceedings were to be advised of their legal rights, including the right to counsel at their own expense; those in exclusion proceedings did not have to be advised of their rights. ${ }^{51}$

Asylum applicants presented their cases before the INS District Director, who determined whether the case was clearly meritorious, clearly lacking in substance, or doubtful. ${ }^{52}$ If doubtful, an advisory opinion was to be solicited from the State Department. ${ }^{53}$ If the asylum request were approved, the alien could be admitted either as a conditional entrant under the seventh preference or could be granted parole. $^{54}$

While the regulations indicated which data were to be solicited from the applicant, no criteria were clearly established. The regulations referred both to the broad, humanitarian Protocol and to the narrow, ideological criteria of the seventh preference, but nowhere did they refer to a "well-founded fear of persecution."

Until the Haitian litigation of the late 1970's, ${ }^{55}$ aliens in exclusion proceedings who were denied asylum requests had no right of appeal except through habeas corpus proceedings in the federal courts. ${ }^{56}$ For those in deportation proceedings, negative decisions could be appealed to the Board of Immigration Appeals

47. U.S. Dep't of State, General Policy for Dealing with Requests for Asylum by ForEIGN Nationals, Jan. 4, 1972, reprinted as Appendix 1 in SubCOMmITtee RePORT, supra note 46, at 17; Roberts, supra note 26 , at 46 . 20.

48. 39 Fed. Reg. 41,832 (1974) reprinted as Appendix 2 in SUbCOMMITTEE REPORT, supra note 46, at

49. 8 C.F.R. $\S 108.2$ (1981) (revoked at 46 Fed. Reg. 45,116, 45,117 (1981)). This provision was no longer applicable following passage of the Refugee Act of 1980 (see infra note 68 and accompanying text), and provisions on admission of refugees are now consolidated in 8 C.F.R. $\S 207$ (1982).

50. Id.

51. Sannon v. United States, 427 F. Supp. 1270, 1273, 1276 (S.D. Fla. 1977), vacated and remanded for consideration of moolness, 566 F.2d 104 (5th Cir. 1977).

52. 8 C.F.R. $\$ 108.2$.

53. Id.

54. 8 U.S.C. $\S 1255$ (1976 \& Supp. 1981). See also 8 C.F.R. $§ 245.2$ (1978) (amended at 43 Fed. Reg. 18,644 (1978)). See generally D. Carliner, The Rights of Aliens: The Basic ACLU Guide to an Alien's. Rights 53 (1977); Evans, supro note 23, at 224.

55. See infia text accompanying notes 123-45.

56. 8 U.S.C. $\S \S 1105 a(a)(7),(a)(9)$ (1976). 
(BIA). ${ }^{57}$ If dismissed by the BIA, those in deportation proceedings could still request withholding of deportation under section $243(\mathrm{~h}) .{ }^{58}$

Withholding of deportation has been granted infrequently and primarily to those who have been members of dissident political groups, active political figures, or those who have been highly critical of their home government. ${ }^{59}$ Historically, asylum has been granted to virtually everyone fleeing any Communist regime except Yugoslavia. ${ }^{60}$ As a State Department official noted, "It's just agreed upon that, if they have fled from a Communist government, they are refugees."61 According to State Department and Immigration officials, it is relatively rare for aliens from Communist countries to be placed in deportation proceedings at all. ${ }^{62}$ They therefore seldom confront the need to request the section $243(\mathrm{~h})$ relief of withholding deportation.

Those fleeing friendly governments have had a much more difficult time obtaining asylum. State Department officials recognize that by granting refugees rights in the United States they imply a denial of rights in the refugees' home countries. "There is no question that, when we grant asylum to a refugee from a government . . . with which we are friendly, that government feels that its reputation is slighted, its honor impugned. This can only lead to resentment against the United States and both governments lose out." 63

Since World War II, leftist totalitarian countries have been unfriendly towards the United States, while most rightist authoritarian countries have been defined as friends. ${ }^{64}$ For those who believe in such a dichotomy, totalitarian governments have no freedoms. In contrast, according to this argument, authoritarian governments have some freedoms. For example, in the House Subcommitee on Immigration hearing on Haitian refugees in 1980, Chairwoman Holtzman asked the State Department's human rights officer for Haiti if there was political freedom at all in Haiti. The only "gleam of light" he could cite was freedom of religion. ${ }^{65}$

By implication, all individuals fleeing totalitarian governments are ipso facto fleeing persecution. Those individuals and the countries friendly to the United States (opposing totalitarianism) deserve help. In contrast, also by implication,

57. 8 U.S.C. $\S 1226($ b) (1976); 8 C.F.R. $\S 236.5$ (redesignated and amended at 43 Fed. Reg. 16,445 (1978), 44 Fed. Reg. 21,259 (1979); now at 8 C.F.R. $\$ 236.6$ (1982)); see Sannon v. United States, 427 F. Supp. 1270, 1274 (S.D. Fla. 1977), vacated and remanded for consideration of mootness, 566 F.2d 104 (5th Cir. 1977).

58. 8 C.F.R. § 108.2. See Subcommittee Report, supra note 46 , at $3-4 ; 1$ C. Gordon \& H. Rosenfeld, Immigration LaW \& Procedure § 2-188.20(6) (rev. ed. 1982); Evans, supra note 23, at 225.

59. Evans, supra note 23, at 251-52. See generally Evans, Political Refugees and the Uniced States Immigration Laws: Further Developments, 66 AM. J. INT'L L. 571 (1972).

60. Note, supra note 41, at 108; Dernis, Haitian Immigrants: Political Refugees or Economic Escapees, $31 \mathrm{U}$. Miami L. ReV. 27, 128 (1976).

61. Note, supra note 41 , at $124 \mathrm{n} .121$.

62. Id. at 131 .

63. Id. at 134 .

64. This section is based upon the author's observations made while serving as a Congressional Fellow 1979-80 in the office of Congressman Mickey Leland. During 1980-81, the author conducted numerous interviews with involved individuals including present and former officials in the INS, the State Department, the White House, the Congress, and human rights groups, plus lawyers for the Haitians.

65. Caribbean Migration, supra note 5, at 234 (statement of Stephen Palmer, Deputy Assistant Secretary of State, Bureau of Human Rights and Humanitarian Affairs). 
authoritarian countries only persecute individuals who are "politically involved," i.e., participants in organized, institutionalized activities such as political parties. Any others fleeing authoritarian governments can only be escaping dire economic conditions. Individuals who may be attempting to avoid extortion by local officials are not fleeing persecution, but personal disputes.

Thus, admitting Haitians as refugees would set a precedent for "opening the floodgates" to immigrants from other authoritarian regimes. ${ }^{66}$ The strategy of the executive branch, therefore, has been substantively to deny the Haitians access to the economic opportunities they are seeking, and ideologically to deny evidence that either blurs the political/economic cleavage or demonstrates that Haitian boat people have been or would be directly subject to persecution in Haiti.

This strategy is reflected in asylum statistics. For 1975 and 1976, the last two years for which asylum statistics are available, the United States granted asylum to $5 \%$ of those fleeing rightist regimes and $95 \%$ of those fleeing Communist countries. ${ }^{67}$

Congress explicitly designed the Refugee Act of 1980 to eliminate this biased and discriminatory treatment. ${ }^{68}$ The Act essentially adopts the Protocol's refugee definition and conforms asylum and section 243(h) procedures to this definition. The Act also removes the discretionary language of section 243(h). ${ }^{69}$ These changes establish a basis for transforming U.S. refugee and asylum policy from a simple tool of the Cold War into a means of implementing broader humanitarian principles.

At least in the admission of refugees from abroad, however, the practice has yet to match the principles. Fully $90 \%$ of the refugees who were admitted in 1980 and 1981 were from Indochina, the U.S.S.R., and Eastern Europe. ${ }^{70}$ For those aliens within the United States requesting asylum, neither of the two largest groupsHaitians and El Salvadorans-have had any significant number of asylum applications approved. ${ }^{71}$

In short, while U.S. asylum law has been increasingly based on broad humanitarian principles, the cold war legacy persists and continues to dominate policy implementation. International and U.S. domestic law define and protect the rights of those fleeing "persecution," but the lack of definitional precision for "persecution" has permitted U.S. officials to persist in defining those escaping Communist regimes as ipso facto fleeing "persecution." In contrast, in the eyes of U.S.

66. Even if one believes that totalitarian governments are the enemies of the United States, U.S. refugee policy may still be ill-designed. It might be better to keep the enemies of communism within their own borders to provide 1981 Polish-style resistance. Conversely, the enemies of rightist authoritarianism, if afforded the protection of the United States, might become pro-United States.

67. See Schey, Black Boat People Founder on the Shoals of U.S. Policy, L.A. Times, June 29, 1980, at V3, col. 1.

68. Pub. L. No. 96-212, 94 Stat. 102 (amending the INA, ch. 477, 66 Stat. 163, codified as amended at 8 U.S.C. $\S \S 1101-1546$ (1976 \& Supp. 1981)); S. ReP. No. 256, 96th Cong., 1st Sess. (1979); H.R. ReP. No. 608,96 th Cong., 1st Sess. (1979).

69. 1 C. GORDON \& H. ROSENFELD, supra note 58 , at $\$ 2-188.17$. (1981)

70. Administration and Congress Consult, Under Terms of the Refugee Act, 1981 WORLD REFUGEE SURVEY 49

71. With regard to Haitians, see Caribbean Migration, supra note 5, at 152 (statement of Rep. Shirley Chisholm). 
policymakers and implementors, those escaping rightist authoritarian regimes are fleeing more selective persecution which requires extensive individual justification and demonstration.

\section{III}

\section{Haitian Migration}

\section{A. Historical Migration}

Undeniably, the Haitian boat people are but one part of a much larger population of Caribbean peoples in the United States. In 1980, there were an estimated 50,000 Barbadians, 500,000 Jamaicans and 150,000 Trinidadians in the United States, with over half of all these in the New York metropolitan area. ${ }^{72}$

Haitians have a long history of migration and temporary sojourns to other countries. For example, working-class Haitians have served as contract laborers harvesting sugarcane in the Dominican Republic for most of this century, while the children of Haiti's small middle and upper classes have traditionally attended schools in France. ${ }^{73}$

Though political opponents of new Haitian presidents had always tended to leave Haiti after power changes, that migration had historically been confined to a small number of the elite. Since Francois Duvalier ("Papa Doc") assumed power in 1958, however, all levels of Haitian society have joined the exodus. ${ }^{74}$

After Papa Doc's ascension to power, the first to leave were the upper class who directly threatened his regime. ${ }^{75}$ Around 1964 , in response to the brutality of the Duvalier regime and the lack of personal and economic security, the black middle class began to leave. ${ }^{76}$ In the next wave, many of the urban lower classes departed. ${ }^{77}$ The primary U.S. destination of these groups has been New York City, where it is estimated there are presently between 200,000 and 300,000 Haitians. ${ }^{78}$ They form a heterogeneous group, reflecting all strata of Haitian society. ${ }^{79}$ While many are legal migrants, others are not; nevertheless, they are seldom pursued by the INS authorities in New York. ${ }^{80}$

These previous migrating classes differ from today's Haitian boat people who cram themselves twenty or thirty at a time into small, barely sea-worthy boats for the perilous 720-mile trip to southern Florida. The boat people are primarily poor, rural, and black. Despite the signs of economic deprivation, the Haitians claim

72. Dominguez \& Dominguez, The Caribbean: Its Implications for the United States, HEADlLINE SERIES No. 253, Feb. 1981 , at 56 .

73. Id.

74. F. Ficklen, supra note 1 , at 16.

75. Id.

76. Id.

77. N. Glick, The Formation of a Haitian Ethnic Group 56-57 (1975) (unpublished Ph.D. thesis, Columbia University); F. Laraque, Haitian Emigration lo New York, 7 Migration Today 28 (1979); M. Laguerre, Haitians in the United States 6 (1978) (unpublished manuscript, Afro-American Studies, Univ. of Cal.-Berkeley)

78. Caribbean Migration, supra note 5, at 138 (statement of Rep. Hamilton Fish).

79. Dominguez, From Neighbor to Stranger: The Dilemma of Caribbean Peoples in the United States, ANTILLES Kesearch Program Occasional Papers, 1975, at 5; see also F. Ficklen, supra note 1, at 24-25.

80. Interview with Virginia Dominquez at Duke Univ., Durham, N.C. (Nov. 1980). 
they are fleeing political persecution. An analysis of current economic and political conditions in Haiti lends credence to their claims.

\section{B. Haitian Economic Conditions}

No one denies Haiti's dismal economic conditions. It is the poorest country in the Western Hemisphere, and the 28 th poorest country in the world. ${ }^{81}$ It also has one of the world's most inequitable distributions of income and wealth, with $.8 \%$ of the population possessing $44.8 \%$ of the wealth. ${ }^{82}$ The World Bank estimates that nearly $90 \%$ of the incomes are lower than the minimum necessary for survival. ${ }^{83}$

Papa Doc's reign of terror, between 1958 and his death in 1971, produced a flight not only of people but also of capital, which led to a decline in the gross national product throughout his reign. ${ }^{84}$ The succession of Jean-Claude Duvalier ("Baby Doc"), in 1971, was hailed as marking an end to terror and a beginning of liberalization. Baby Doc himself has claimed that he is ushering in an economic revolution which will transform $\mathrm{Haiti}$ into a peaceful, stable society, progressing toward democracy, human rights, and material prosperity. ${ }^{85}$

Manufacturing activity has, in fact, greatly increased under Baby Doc's rule, especially in the assembly sector. ${ }^{86}$ Having the Western Hemisphere's lowest wages and being in close proximity to the United States, Haiti offers an unparalleled opportunity for investors. Profits can be extraordinarily high-30\% to $50 \%$ on equity - and capital per worker is very low $-\$ 700$ to $\$ 3,500 .{ }^{87}$ Yet the effect of the increase in productivity on the masses has been negligible. Between 1960 and 1979, gross domestic product per capita growth was .9\% annually. ${ }^{88}$ Furthermore, income disparities between rural regions (which contain $75 \%$ to $90 \%$ of the population, depending upon the definition) and urban areas are increasing. ${ }^{89}$ In this context, money remitted to Haiti by expatriates can be critical to a family's survival. It is estimated that Haitians abroad send back $\$ 100,000,000$ each year in hard currency, ${ }^{90}$ nearly as much as the combined total of Haiti's foreign aid. ${ }^{91}$

\section{Haiti's Political Economy}

It must be recognized that for Haiti--perhaps more than for any other country in the nonsocialist world-the term "political economy" is most appropriate. It is

81. 1978 World Bank Atlas: Population, Per Capita Product, and Growth Rates (chart includes only countries with populations of $1,000,000$ or more).

82. W. Fauntroy, The Haitian Refugees and the World House 5 (1980) (unpublished manuscript, prepared while serving as a U.S. Congressman).

83. Id. at 6.

84. 1978 WORLD BANK ATLAS, supra note 81

85. M. Lundahl, Peasants and Poverty: A Study of Haiti (1979).

86. INTER-AMERICAN DEVELOPMENT BANK, OPPORTUNITIES FOR INDUSTRIAL INVESTMENT IN HAITI at iii-iv (1979).

87. Id. at iv.

88. Id. at 278 .

89. Roberts, Impediments to Economic and Social Development in Haiti 8 (June 19, 1978) (Congressional Research Service).

90. James Allman (1981) (unpublished research, available at Columbia University).

91. Economic Section, U.S. Embassy, Port au Prince, Haiti, Economic Trends for Haiti 9 (Nov. 1, 1981). 
estimated that nearly $50 \%$ of the state's income ends up in private hands. ${ }^{92}$ Duvalier controls a vast state monopoly, Regie de Tabac, which exercises exclusive control over distribution of necessities such as fish, cotton, all types of milk and milk products, as well as items such as wine, champagne, whiskey, rum, perfume, dental products, soap, bandages, air conditioners, autos, airplanes, and most electrical appliances. ${ }^{93}$ In 1977 Regie de Tabac was estimated to have collected about $\$ 1,000,000$, but only $\$ 580,000$ reached the public treasury. ${ }^{94}$

Corruption aside, the government's policies are ill-designed to correct Haiti's problems of massive rural poverty. While $90 \%$ of the population is rural, $83 \%$ of government expenditures are in Port-au-Prince, the nation's capital, and agricultural expenditures never exceed $7 \%$ to $10 \%$ of the budget. ${ }^{95}$ The tax structure is highly regressive, ignoring luxury imports and targeting the basic commodities produced and consumed by peasants. ${ }^{96}$

\section{Political Repression}

In the midst of this grinding poverty and corruption, arbitrary repression and persecution have been the hallmarks of both Duvalier regimes. In 1973, Amnesty International stated:

Haiti's prisons are still filled with people who have spent years in detention without ever being charged or brought to trial. . . . The variety of torture is incredible: clubbing to death, maiming the genitals, food deprivation to the point of starvation, and insertion of red-hot pokers into the back passage. In fact, these prisons are death traps and find a parallel with the Nazi concentration camps of the past but have no present-day equivalent. ${ }^{97}$

Recently, under oath in a U.S. federal district court, a former State Department desk officer for Haiti described the regime as the "most oppressive regime in the hemisphere." 98

In 1979, Baby Doc allowed the formation of political parties and then promptly arrested the leaders of one. ${ }^{99}$ The government imposed censorship on the theater in order to close down a Creole-language play that was critical of the government. ${ }^{100}$ In October 1979, a press law was passed that made it illegal to insult the "President for Life," his mother, or other government officials. ${ }^{101}$ Between November 1980 and February 1981, police arrested more than 100 of Haiti's leading independent journalists, human rights activists, and opposition party leaders. ${ }^{102}$

92. Roberts, supra note 89 , at 18 .

93. LAWYERS COMM. FOR INT'L HUMAN RightS, RESPECT FOR HUMAN Rights in Haiti 25 (1980).

94. Caribbean Migration, supra note 5, at 246 (statement of Michael Posner, Exec. Dir., Lawyer's Comm.

for Int'l Human Rights).

95. W. FAUNTROY, supra note 82 , at 5.

96. Roberts, supra note 89 , at 20 .

97. Church World Service, Haitian Refugees Need Asylum: A Briefing Paper 3 (Apr. 9, 1980).

98. Haitian Refugee Center v. Civiletti, 503 F. Supp. 442, 475 (S.D. Fla. 1980), modified sub nom. Haitian Refugee Center v. Smith, 676 F.2d 1023 (5th Cir. 1982).

99. Id. at 504-05.

100. Payne, 'Baby Doc' Takes Charge, 231 The Nation 694, 696 (1980).

101. Id.

102. LAWYERS COMM. FOR INT'L HUMAN RIGHTS, RECENT VIOLATIONS OF HUMAN RightS IN 
This obvious official repression is in addition to the terror and lawlessness which characterize the countryside, where government officials frequently live solely by extortion. It is this latter, less formal, and less visible repression that led one observer to characterize the Haitian government as a "kleptocracy," a government by thieves from the highest to the lowest levels. ${ }^{103}$

\begin{abstract}
Arbitrary arrest, abduction, prolonged detention, severe mistreatment of prisoners and harassment of ordinary citizens by government security forces are common occurrences. These practices continue virtually unchecked by the government. Little value is placed on the Rule of Law; practically nothing has been done to develop institutional structures through which these basic violations can be ended.

. A survey published by the weekly magazine Petit Samedi Soir in August 1979, revealed that $93 \%$ of the respondents felt insecure under the "liberalized" rule of JeanClaude Duvalier, and that over $80 \%$ feel that the country does not offer sufficient guarantees for the protection of human rights. Immediately following publication of this poll, the government arrested three people associated with the magazine. ${ }^{104}$
\end{abstract}

In Haiti repression is not limited to those who engage in organized opposition to the government. "Political prisoners" include those persons who offend the government in any way. One ex-political prisoner simply states: "Politics and everyday life in Haiti cannot be separated. A man can casually say that he is hungry and that can be misconstrued to mean he is criticizing the governmental mismanagement of funds [and this criticism leads] to his arrest." ${ }^{105}$ Jeanton Colas, a major designer of urban development projects in Haiti, was arrested and told during his interrogation that his refusal to support the Duvalier government overtly made him suspect. ${ }^{106}$ Musicians with no obvious political affinities have also been mistreated. Fritzer Sidney and Prosper Saint-Louis were arrested for having sung a song with antigovernment connotations. Both were held incommunicado and severely beaten. Saint-Louis was held in prison for four months without the opportunity to inform his paralyzed wife and four children that he was still alive. ${ }^{107}$

In some cases, simply having been abroad, regardless of one's activities within or outside of Haiti, has been sufficient to elicit persecution. ${ }^{108}$

I flew back to Haiti on Monday, February 18, 1977, and was immediately arrested at the airport. They immediately confiscated the $\$ 1,700$ that $I$ had in my wallet for my mother's operation . . . They then took me to a prison on the outskirts of Port-au-Prince that $I$ recognized as Fort Dimanche at about 6:00 p.m. after beating me.

At Fort Dimanche they beat me twice daily on a regular basis, every morning and evening. ... For six days the beatings were the same, they would come in the cell and punch and kick me all over, and hit me with a club . . . . I lost six teeth as a result of these beatings and began to lose consciousness more and more frequently.

On Thursday morning just before they entered our cells to beat us, I heard one of the guards say to the other, "Some of the people here are from Miami, and one is from the

HAITI: AN UPDATE OF THE JUNE 1980 REPORT OF THE LAWYERS COMMITTEE FOR THE INTER NATIONAL human Rights Submitted to the United Nations, ECOSOE Resolution 1503 (XLVIII) i (1981).

103. M. LUNDAHL, supra note 85 , at 357.

104. Caribbean Migration, supre note 5, at 3-4.

105. Id. at 12 .

106. Id. at 16 .

107. Id. at 16 .

108. Id. at $38-42$. 
Bahamas. They're political, they're against Duvalier and we have to kill them."109

A former member of the infamous security forces, the Tonton Macoutes, ${ }^{10}$ has been quoted as stating:

Publicly, Jean-Claude Duvalier said that people who are returned to Haiti . . . would be allowed to return to their homes without any problem. But . . . he simultaneously gave orders in secret to the military and the Tonton Macoutes that returning deportees from the United States and other countries should always be arrested. Everyone who leaves Haiti illegally and then returns is put in jail. The order is still standing and has never been revoked. ${ }^{111}$

Another former Tonton Macoute stated that "returnees received 'especially brutal treatment,' being constantly beaten about the head and kept tied up in jail cells." 112

Even the Haitian Government admits to the widespread denial of justice. In its preliminary observations on the April 1980 Report of the Inter-American Commission on Human Rights of the Organization of American States (IACHR), the Haitian Government explained: "Even though the law is still violated at every level, despite the improvements introduced over the last seven years, violations are most often due to the fact that this administration is overburdened, understaffed, or does not act unless pressure is applied." 113

Conditions in Haiti may be summarized as follows: Poverty is extreme and pervasive; the Haitian Government does virtually nothing to improve the general welfare of the masses but rather exploits and exacerbates existing conditions; and repression is pervasive and triggered by the slightest imagined opposition.

\section{IV}

\section{Haitians in the United States}

\section{A. The Constellation of Forces}

The first Haitians to request political asylum did so in September 1963, after having been taken into custody by the INS upon their arrival in Florida. ${ }^{114}$ These claims, as well as almost all subsequent Haitian claims for political asylum, have been denied under both the asylum regulations and section 243(h). ${ }^{115}$

Since 1972, national political authorities, goaded by local political groups, have attempted both to deter Haitian immigration and to deport those Haitians

109. Id. at $41-43$.

110. The Tonton Macoutes are Haiti's infamous nonsecret, secret police created by Francois Duvalier. Numerous accounts have described their rapacious but effective efforts in maintaining order through extortion and repression. They were officially banned by Jean-Claude Duvalier but have persisted as visibly as before. LAWYERS COMM. FOR INT'L HUMAN RIGHTS, supra note 102, at 11, provides a brief, accurate summary of their role in Haitian society.

111. Church World Service, supra note 97, at 16 (citation omitted).

112. Crankshaw, Haitian Refugees Facing Abuses If Retumed, Witness Tells Court, Miami Herald, Nov. 24, 1979, at A1, col. 5 .

113. INTER-AMERICAN COMMISSION ON Human Rights, OAS, RePORT ON ThE STATUS OF Human Rights in HaIti 40 (1980), reprinted as Appendix I in Caribbean Refugee Crisis: Cubans and Haitians: Hearings Before the Senate Comm. on the Judiciary, 96th Cong., 2d Sess. 66 (1980).

114. SUBCOMMITTEE REPORT, supra note 46 , at 1 .

115. Id.; see also Haitian Refugee Center v. Civiletti, 503 F. Supp. 442, 511, 528 (S.D. Fla. 1980), modifed sub. nom. Haitian Refugee Center v. Smith, 676 F.2d 1023 (5th Cir. 1982). 
already in Florida. ${ }^{116}$ Members of south Florida's political elite-including Democratic party members, elected officials, and some Cubans-believed that the boat people were a disruptive force, destroying the community and draining public resources. They appealed to their local Congressmen, who apparently pressured the INS into a response. ${ }^{117}$ The INS thereafter began to expend a far greater effort in controlling the flow of Haitians than was expended on nearly any other group of illegal immigrants. ${ }^{118}$

While the government has been attempting to expel the Haitian boat people, nongovernmental groups at local and national levels, and groups within Congress, have been diligently working to obtain permanent legal status for the Haitians. In Miami the most visible supporters of the Haitians have been second-generation Cuban-Americans, the liberal branch of Florida's Democratic party, the established Haitian community, the churches, and the media. Organized support from Miami's blacks has been narrowly based, possibly due to a lack of political organization rather than a lack of sympathy. 119 At the national level, church groupsparticularly the National Council of Churches-were the first to become involved. They were followed by public interest lawyers, national black groups (particularly the Congressional Black Caucus), and other civil rights organizations, unions, and eventually state and local officials with a fiscal interest in legalizing the Haitians' status. ${ }^{120}$

\section{B. The Haitians and the Courts}

After denial of refugee status by the INS, Haitians have repeatedly sought relief through the courts, with mixed results. The laws, regulations, and court decisions in previous Haitian and non-Haitian refugee cases have been sufficiently ambiguous and contradictory to provide the courts ample grounds to justify opposite findings in virtually identical cases.

In presenting their cases, the Haitians' lawyers have usually argued not that every Haitian deserves asylum, but that they do deserve a full and fair hearing. They claim that the INS has arbitrarily and capriciously dismissed their claims as frivolous. ${ }^{121}$

When denying redress to Haitians, the courts have reiterated a number of arguments:

1. Asylum cases are decided at the discretion of the Attorney General and the INS District Director. Under the Administrative Procedure Act (APA), ${ }^{122}$ the law

116. See supra note 64 .

117. Interview with a former INS official who requested anonymity (Nov. 1981).

118. The only recent comparable cases are those of Iranians during the hostage crisis 1979-80 and El Salvadorans during their country's civil war.

119. Personal interviews with numerous involved parties from Miami, Washington, and New York (July-Sept. 1981).

120. Id.

121. Interview with Ira Kurzban, co-counsel for the plaintiffs in Haitian Refugee Center v. Civiletti, 503 F. Supp 442 (S.D. Fla. 1980), modifed sub. nom. Haitian Refugee Center v. Smith, 676 F.2d 1023 (5th Cir. 1982) (claim raised and decided in the plaintiffs favor).

122. Ch. 324, 60 Stat. 237 (1946)(codified as amended at 5 U.S.C. $\$ \S 552-559,701-706$, plus scattered sections (1976 \& Supp. 1981)). 
governing judicial review of federal agency actions, such discretionary decisions can be examined only to determine whether they represent an arbitrary and capricious abuse of authority. ${ }^{123}$ They cannot be reviewed on the merits. ${ }^{124}$

2. Aliens in exclusion proceedings may constitutionally be deprived of rights available to citizens or to aliens who have effected either legal or illegal entry into the United States. ${ }^{125}$

3. Individual aliens must bear the burden of proving likelihood or "clear probability" of persecution. ${ }^{126}$

4. Government persecution cannot be of a general nature, but must be directed at the individual claiming asylum. ${ }^{127}$

5. Persecution must be politically motivated, as evidenced by the applicant's explicit opposition to the regime and participation in organized political activity. ${ }^{128}$

6. Past persecution does not ipso facto demonstrate a likelihood of future persecution. ${ }^{129}$

7. Prosecution for having left a country and having sought political asylum in the United States does not amount to persecution within the meaning of the statutes and regulations. ${ }^{130}$

8. The courts will not be abused by allowing dilatory tactics to delay deportation or exclusion proceedings. ${ }^{131}$

9. The court has no jurisdiction to infringe upon the political decisions of the legislative branch. ${ }^{132}$

In those cases favoring Haitian asylum claims, the courts have advanced these arguments:

1. Failure to take into account alleged conditions of individual or, in some

123. 5 U.S.C. $§ 706(2)$ (a) (1976).

124. See, e.g., Fleurinor v. INS, 585 F.2d 129, 133 (5th Cir. 1978); Paul v. INS, 521 F.2d 194, 197 (5th Cir. 1975); Gena v. INS, 424 F.2d 227, 232 (5th Cir. 1970); see also Pierre v. United States, 547 F.2d 1281, 1289 (5th Cir.), vacaled and remanded for consideration of mootness, 434 U.S. 962 (1977).

125. See, e.g., Kleindienst v. Mandel, 408 U.S. 753, 769-70 (1972); Pierre v. United States, 547 F.2d 1281 , 1289-90 (5th Cir.), vacaled and remanded for consideration of mootness, 434 U.S. 962 (1977); Fiallo v. Levi, 406 F. Supp. 162, 165 (E.D.N.Y. 1973), affd sub nom. Fiallo v. Bell, 430 U.S. 787 (1977).

126. See, e.g., Fleurinor v. INS, 585 F.2d 129, 133 (5th Cir. 1978); Pierre v. United States, 547 F.2d 1281, 1289 (5th Cir.), vacaled and remanded for consideration of mootness, 434 U.S. 962 (1977); Cisternas-Estay v. INS, 531 F.2d 155, 159 (3d Cir.), cert. denied, 429 U.S. 853 (1976); Paul v. INS, 521 F.2d 194, 200 (5th Cir. 1975); Gena v. INS, 424 F.2d 227, 232-33 (5th Cir. 1970).

127. See, e.g., Fleurinor v. INS, 585 F.2d 129, 133 (5th Cir. 1978); Paul v. INS, 521 F.2d 194, 199, 201 (5th Cir. 1975); Gena v. INS, 424 F.2d 227, 233 (5th Cir. 1970); Lena v. INS, 379 F.2d 536, 538 (7th Cir. 1967).

128. See, e.g., Pierre v. United States, 547 F.2d 1281, 1289 (5th Cir.), vacated and remanded for consideration of mootness, 434 US. 962 (1977); Paul v. INS, 521 F.2d 194, 200 (5th Cir. 1975); Gena v. INS, 424 F.2d 227, 233 (5th Cir. 1970); Hyppolite v. INS, 382 F.2d 98, 100 (7th Cir. 1967).

129. See, e.g., Fleurinor v. INS, 585 F.2d 129, 134 (5th Cir. 1978); Gena v. INS, 424 F.2d 227, 233 (5th Cir. 1970).

130. See Coriolan v. INS, 559 F.2d 993, 1000 (5th Cir. 1977) (reversing immigration judge's conclusion of such for failure to consider all relevant factors); $c f$. In re Vardjan, 10 I. \& N. Dec. 567, 577 (1964) (involving a Yugoslavian).

131. Fleurinor v. INS, 585 F.2d 129, 133 (5th Cir. 1978)

132. Kleindienst v. Mandel, 408 U.S. 753, 765-67 (1972); see also Fleurinor v. INS, 585 F.2d 129, 134 n.2 (5th Cir. 1978). 
instances, even general persecution, can be labeled arbitrary and capricious. ${ }^{133}$

2. Statutory law permits judicial review of the INS District Director's denial of asylum claims. ${ }^{134}$

3. All aliens have a right to a full and fair opportunity to present evidence supporting their claims of persecution. ${ }^{135}$

4. If supplementary information becomes available and is material, the aliens have a right to reopen the hearing. ${ }^{136}$

5. Persecution may occur in the absence of overt political action, and political conditions may be so oppressive that a wider range of claims, including deprivation of economic livelihood, must be given credence. ${ }^{137}$

-6. A court may examine the conditions in the country from which the applicant has fled to determine whether a District Director's decision was arbitrary or capricious. Such an examination is not an infringement on the political prerogatives of the executive branch. ${ }^{138}$

The split of judicial opinion is dramatically captured in the Fifth Circuit's opinion in Paul $v$. INS. ${ }^{139}$ Petitioners asked the court to remand their asylum cases to the INS so that they might adduce specific additional evidence of persecution in Haiti. One petitioner had been imprisoned for twenty days; the brother of another was killed and relatives had to change their names and addresses; the father and mother of a third died in prison after being tortured; the police broke into the home of a fourth and told him that if he did not leave Haiti the police would kill him; another wrote a letter to Jean-Claude Duvalier and was arrested for plotting against the regime. ${ }^{140}$ These petitioners, as well as others not described here, wished to introduce new evidence. ${ }^{141}$

The majority found against the petitioners concluding, "We do not find the evidence which petitioners seek to adduce material." 142 The majority further held that the petitioners had no valid excuse for not having offered the evidence earlier. The court limited its review to judging whether the district director's use of authority was arbitrary and capricious and found the denials of asylum to be 'neither. Making the assumption that the evidence cited above was substantially

133. Haitian Refugee Center v. Civiletti, 503 F. Supp. 442, 528 (S.D. Fla. 1980), modified sub nom. Haitian Refugee Center v. Smith, 676 F.2d 1023 (5th Cir. 1982); Coriolan v. INS, 559 F.2d 993, 1000,1002 (5th Cir. 1977); In re Joseph, 13 I. \& N. Dec. 70, 73-74 (1968)

134. Coriolan v. INS, 559 F.2d 993, 1003 (5th Cir. 1977)

135. Sannon v. United States, 427 F. Supp. 1270, 1276-77 (S.D. Fla. 1977), vacated and remanded for consideration of mootness, 566 F.2d 104 (5th Cir. 1977); of. In re Sihasele, 11 I. \& N. Dec. 759, 763 (1966) (involving an Indonesian).

136. Coriolan v. INS, 559 F.2d 993, 1003-04 (5th Cir. 1977); United States ex rel. Mercer v. Esperdy, 234 F. Supp. 611,617 (S.D.N.Y. 1964).

137. Coriolan v. INS, 559 F.2d 993, 1001, 1003 (5th Cir. 1977); United States ex rel. Mercer v. Esperdy, 234 F. Supp. 611, 616-17 (S.D.N.Y. 1964).

138. Haitian Refugee Center v. Civiletti, 503 F. Supp. 442, 472 (S.D. Fla. 1980), modified sub nom. Haitian Refugee Center v. Smith, 676 F.2d 1023 (5th Cir. 1982); Coriolan v. INS, 559 F.2d 993, $1001-02$ (5th Cir. 1977); see also In re Joseph, 13 I \& N. Dec. 70, 72 (1968) (reviews conditions in Haiti without discussing infringement issue).

139. Paul v. INS, 521 F.2d 194 (5th Cir. 1975).

140. Id. at 203-04.

141. Id. at 196 .

142. Id. at 201. 
credible, the dissenting opinion stated, "[T]he conclusion that petitioners failed to meet the burden of proof is, to put it baldly, astonishing." 143

C. The Haitian Program and its Aftermath: Judicial-Executive Branch Interactions

In the face of this judicial ambivalence the INS continued to operate under the assumption that the boat people were not politically motivated but were arriving for purely economic reasons. ${ }^{144}$ They attempted to discourage further migration by making it as difficult as possible for incoming Haitians to find work. Most Haitians were detained-in some cases as far away as El Paso, Texas-with bond set at a minimum of $\$ 500 .{ }^{145}$ Additionally, the INS denied work authorization to those who were released on bond. ${ }^{146}$

The INS policy, however, had no visible deterrent effect; rather, the number of boats arriving gradually increased. ${ }^{147}$ Soon southern Florida's prisons were overcrowded with Haitians living in conditions appalling even to the INS authorities responsible for placing them there. ${ }^{148}$

In 1977, events accelerated. Leonel Castillo was appointed INS Commissioner, the first ethnic minority person to hold that position. The Service's Haitian policy softened somewhat. The INS announced that it was on the verge of issuing new asylum regulations which would grant the Haitians the rights they were seeking through the courts. ${ }^{149}$ Asylum regulations would be written in accordance with the 1967 UN Protocol and individuals in exclusion proceedings would receive the same rights as those in deportation proceedings. Moreover, the INS agreed to release Haitians without bond and to issue them work authorizations while their asylum hearings were pending. ${ }^{150}$

Although the agreement stipulated issuance of work authorizations only to Haitians who were "known," the INS publicly announced that any Haitian who presented himself to the INS would receive a work authorization. About 5,000 Haitians came forward and received work authorizations. ${ }^{151}$ Many had had no previous contact with the INS.

While this policy reflected a humanitarian attitude toward the Haitians, it produced a substantial backlash. Miami INS staffers and other members of the community objected to the plan and pressured the Attorney General to revoke the

143. Id. at 204.

144. See supra note 64 .

145. Church World Service, supra note 97 , at 10.

146. Id. INS).

147. Caribbean Migration, supra note 5, at 200 (statement of David Crosland, Acting Commissioner,

148. Interview with INS official who requested anonymity (Nov. 1981). INS).

149. Caribbean Migration, supra note 5, at 200 (statement of David Crosland, Acting Commissioner,

150. Letter from David Crosland, INS General Counsel, to Sue Sullivan, National Council of Churches (Nov. 8, 1977) (File No. C0 1170-C)

151. National Council of Churches v. Egan, No. 79-2959 Civ.-WMH (S.D. Fla. July 1979); LAWYERS COMM. FOR INT'L HUMAN RightS, INT'L HUMAN RightS LAW GROUP \& WaSH. LAWYERS COMM. FOR Civil Rights Under LaW, Alien Rights law Project, The Haitians in Miami: Current Immigration Practices in the United States 4 (Dec. 1978). 
work authorizations. Soon thereafter the INS reversed the new policy. ${ }^{152}$

After visiting Miami to review the Haitian refugee situation, which by then involved a backlog of over 5,000 asylum claims, ${ }^{153}$ a top INS official decided that the "most practical deterrent to this problem [was] expulsion from the United States."154 Officials in the Justice Department and the INS then designed the "Haitian Program."

The two principal thrusts of the program were to deny Haitians access to lawyers and to prejudge any Haitian claims for asylum. The INS would not only fail to advise Haitians of their right to a lawyer but would also tell arriving Haitians that an attorney would get them in trouble. ${ }^{155}$ To deter pro bono lawyers from informing Haitians of their rights to claim asylum and have a lawyer, INS posted a guard in its Miami offices. ${ }^{156}$ Moreover, the documents of some Haitians who had requested lawyers were falsified to state that they had not requested lawyers. ${ }^{157}$

Hearings were speeded up, making it impossible for those Haitians who did have lawyers to prepare or present adequate asylum cases. The INS suspended one of its own regulations requiring that deportation hearings be halted for any individual who had filed a political asylum application. ${ }^{158}$ Under the speedup program lawyers had only thirty minutes to prepare cases, though the normal preparation time for an asylum claim was twenty hours. ${ }^{159}$ There was no time to collect either documents or witnesses. The United Nations High Commission on Refugees (UNHCR), which sent representatives to Miami during the mass processing period, claimed that only $45 \%$ of all Haitian asylum applicants were even interviewed before their claims were denied by the INS. ${ }^{160}$

Before the speedup, the INS processed fewer than half a dozen Haitian asylum claims a day (indeed, they processed less than ten a day for all nationalities). ${ }^{161} \mathrm{By}$ July 1978, Haitian cases had climbed to fifty-five claims processed per day, and by September, more than one hundred. ${ }^{162}$ The INS scheduled a dozen or more asylum interviews and deportation hearings for the same hour. Attorneys were frequently expected to appear in fifteen different cases and five different locations at the same time. An INS official testified that it would have been "too cumbersome" for the agency to have coordinated the scheduling of hearings to avoid time conflicts. ${ }^{163}$

152. Interview with Leonel Castillo, former INS Commissioner (Nov. 12, 1982).

153. Haitian Refugee Center v. Civiletti, 503 F. Supp. 442, 511 (S.D. Fla. 1980), modifued sub nom. Haitian Refugee Center v. Smith, 676 F.2d 1023 (5th Cir. 1982).

154. Crewdson, Ruling Nears in Haitians' Lawsuil Alleging U.S. Bias, N.Y. Times, June 12, 1980, 2t Al, col. 4 , D18, col. 1 .

155. Id.

156. Id.

157. Id.

158. Id.

159. Haitian Refugee Center v. Civiletti, 503 F. Supp. 442, 522, 525 (S.D. Fla. 1980), modifred sub nom.

Haitian Refugee Center v. Smith, 676 F.2d 1023 (5th Cir. 1982).

160. Id.

161. Id. at 523; Crewdson, supra note 154 , at D18, col. 1.

162. Crewdson, supra note 154 , at D18, col. 3 .

163. Haitian Refugee Center v. Civiletti, 503 F. Supp. 442, 524 (S.D. Fla. 1980), modified sub nom. Haitian Refugee Center v. Smith, 676 F.2d 1023 (5th Cir. 1982). 
Proceedings, which formerly averaged ninety minutes, were shortened to less than half an hour. ${ }^{164}$ When lawyers attempted to intercede on behalf of their clients, the immigration judges ordered them to remain silent. If the lawyers persisted, the judges threatened them with disciplinary proceedings. ${ }^{165}$ On some occasions, Haitians angered the immigration judges by invoking their fifth amendment privilege against self-incrimination; these Haitians were thrown in jail. ${ }^{166}$ The INS later admitted it did not possess the authority to jail anyone for invoking the fifth amendment. ${ }^{167}$

For those immigrants who did attempt to plead their cases, much was lost in the translation. Detailed, extensive evidence of persecution in Haiti as a motivation for coming to the United States became after translation, "I came here to find work." 168 At the conclusion of these abbreviated asylum hearings, forms representing denial of asylum claims were presented to the Haitians. The forms had been prepared in advance and presigned by the INS District Director. ${ }^{169}$

When the Haitian Program commenced, the government had not yet issued the new asylum regulations promised nearly a year earlier. In September 1978, Judge King of the southern district court of Florida, held a hearing to discern why the government had not yet issued the new regulations. ${ }^{170}$ When he discovered that, in addition to having not yet issued new regulations, the INS had initiated a massive streamlined deportation process, the judge inveighed against the government attorney. The next day, the new regulations were issued. ${ }^{171}$

Haitian advocates quickly challenged the regulations, claiming that they violated the Administrative Procedure Act because they had not been preceded by notice and time for public comment and that they did not assure due process for asylum claims as originally promised. ${ }^{172}$

In October 1978, Judge King continued a stay of exclusion proceedings pending revisions of the regulations. ${ }^{173}$ In April 1979, the reissued regulations for asylum hearings appeared in the Federal Register. ${ }^{174}$ Again, Haitian advocates challenged them, this time on the grounds that they would not sufficiently notify the Haitians of their rights. ${ }^{175}$ Meanwhile, pending settlement negotiations in a separate class action, Judge King, in July 1979, enjoined the INS from executing final orders of deportation. ${ }^{176}$ This order effectively halted the Haitian Program. Then, in January 1980, he issued an opinion on the challenge to the regulations,

164. Id. at 527

165. Id. at 521 .

166. Crewdson, supra note 154 , at D18, col. 1 .

167. Id.

168. Id.

169. Haitian Refugee Center v. Civiletti, 503 F. Supp. 442 (S.D. Fla. 1980), modified sub nom. Haitian Refugee Center v. Smith, 676 F.2d 1023 (5th Cir. 1982).

170. Interview with Kurzban, supra note 121.

171. Id.

172. Sannon v. United States, 460 F. Supp. 458, 461-62 (S.D. Fla. 1978)

173. Id.

174. 44 Fed. Reg. 21,253, 21,256 (1979).

175. See Sannon v. United States, 631 F.2d 1247, 1250 (5th Cir. 1980).

176. Haitian Refugee Center v. Bell, No. 79-2086 Civ.-JLK (S.D. Fla. July 25, 1979), appeal from continuation of stay dismissed sub nom. Haitian Refugee Center v. Civiletti, 614 F.2d 92 (5th Cir. 1980). 
ordering a six-month program of notification through radio broadcasts and the newspapers of Haitians' rights concerning political asylum. ${ }^{177}$

In July 1979, Haitian advocates filed suit claiming that the Haitian Program's revocation of the Haitian work authorizations violated the UN Protocol, the National Council of Churches-INS agreement which released the Haitians, and the Administrative Procedure Act. ${ }^{178}$ After failing to convince the court to dismiss the case, the government agreed in October 1980, to issue work authorizations to all Haitians over sixteen years of age seeking political asylum, who were in the United States on or before June 19, 1980, and who had undergone initial processing by the INS on or before August 1, 1980. ${ }^{179}$

\section{Haitian Refugee Center v. Civiletti}

The most celebrated and comprehensive case concerning Haitians, Haitian Refugee Center v. Civiletti, ${ }^{180}$ was filed in May 1979. The class action complaint had two fundamental thrusts: that the Haitian Program was a massive violation of the rights of the Haitian boat people; and that the government had unfairly prejudged the Haitians' claims for political asylum. The sixteen-count complaint averred that the government's special eight-month Haitian Program was fatally defective on both constitutional and statutory grounds. While the plaintiffs sought no relief with respect to the substance of their asylum applications, they did seek an opportunity for a fair and nondiscriminatory reprocessing of their claims. A three-week trial was held in April 1980.

Argument in the case was both complex and extensive. The plaintiffs introduced into the record considerable amounts of material detailing the INS's alleged improper handling of the Haitian asylum claims, along with specific evidence of persecution in Haiti against many members of the class. They also presented lengthy detail on general conditions of poverty and oppression in Haiti.

While the defense employed all of the arguments previously successful in court cases which had dismissed Haitian asylum claims, it placed greatest emphasis upon the report of a State Department team of experts who had gone to Haiti in July 1979 to search for returnees. ${ }^{181}$ The team consisted of white, non-Creolespeaking State Department employees who searched for 700 or more Haitians who had been deported or voluntarily returned to Haiti. They found and interviewed eighty-six, none of whom, according to the report, acknowledged having been persecuted or otherwise mistreated. ${ }^{182}$

The plaintiffs countered this evidence with expert human rights testimony,

177. Sannon v. United States, No. 74-428 Civ.-JLK (S.D. Fla. Jan. 7, 1980) (final order entered) (other portions of the order were vacated as moot at 631 F.2d 1247 (5th Cir. 1980)).

178. American Civil Liberties Union of Florida, Government Settles Law Suit by Hatian Refugees for Work Authorizations 1-2 (Oct. 21, 1980) (news release).

179. National Council of Churches v. Shenefeld, No. 792959 Civ.-ALH (S.D. Fla. 1980).

180. Haitian Refugee Center v. Civiletti, 503 F. Supp. 442 (S.D. Fla. 1980), modified sub nom. Haitian Refugee Center v. Smith, 676 F.2d 1023 (5th Cir. 1982).

181. Id. at $482-93$.

182. Id. 
including a presentation from Amnesty International. ${ }^{183}$. This testimony asserted that the State Department's method was defective on several grounds: the sample was unrepresentative, the team made no effort to determine if any of the returnees might be in prison, and the respondents had little incentive to tell the truth concerning persecution and were offered little protection from future persecution if they did tell of persecution. In short, according to this testimony, the report proved nothing concerning the fate of returnees. To further refute the State Department report, the plaintiffs presented a witness who had previously worked for the Haitian Government and who claimed knowledge of and participation in Haitian government persecution of returnees. ${ }^{184}$ The defense had no countervailing witnesses, but questioned the credibility of this witness, who was himself claiming political asylum.

Judge King's opinion, issued on July 2, 1980, did not equivocate: "Haitians who came to the United States seeking freedom and justice did not find it."185 Instead, "they were confronted with an Immigration and Naturalization Service determined to deport them irrespective of the merits of their asylum claims."186 The INS actions, however, were not a new phenomenon. "Over the past 17 years, Haitian claims for asylum and refuge have been systematically denied, while all others have been granted. The recent Haitian Program is but the largest-scale, most dramatic example of that pattern."187 The Court dismissed the government's contention that nearly all Haitians in the United States were merely seeking better economic conditions and faced no threat of political persecution upon return. "[T]he Court has seen a stark picture of how these plaintiff-immigrants will be treated if they return to Haiti. And it has seen an equally stark, and even more troubling, picture of the treatment of the Haitians by the Immigration and Naturalization Service."188

In an unusually scathing judicial criticism of an executive agency, Judge King also suggested that officials of the service had been motivated, to some degree, by racial prejudice. "The plaintiffs are part of the first substantial flight of black refugees from a repressive regime to this country." 189 While admitting prejudice of any type is seldom overt, Judge King asserted he could place no other interpretation on some key pieces of evidence including an internal immigration service memorandum asserting that the Haitians threatened the economic and social "well-being" of Miami. ${ }^{190}$

The ruling strongly condemned both the United States and Haitian Governments and provided findings of fact which clearly suggested that the Haitians had a "well-founded fear of persecution." Nevertheless, the ruling stopped short of

183. Id. at 476-82. See also Affidavits concerning the State Department Study Team on Haitian Returnees, Dr. George Anglade (Nov. 22, 1979), Michelle Bogre (Apr. 16, 1979).

184. Haitian Refugee Center v. Civiletti, 503 F. Supp. 442, 477-79 (S.D. Fla. 1980), modified sub nom. Haitian Refugee Center v. Smith, 676 F.2d 1023 (5th Cir. 1982).

185. Id. at 532 .

186. Id.

187. Id. at 519

188. Id. at 450 .

189. Id. at 451 .

190. Id. at 517 . 
extending permanent legal status to the Haitians. Instead it returned that function to the executive branch, ordering the INS to follow the principles of due process and equal protection in formulating a plan for reprocessing the Haitians' asylum claims.

\section{E. Related Developments}

Judge King's decision concerning Haitian refugees was delivered in the midst of a U.S. refugee crisis of much larger proportions. On March 15, 1980, President Carter had signed the Refugee Act of 1980, ${ }^{191}$ eliminating bias in favor of those fleeing Communist countries and against those fleeing countries such as Haiti. On April 19, 1980, the Mariel sealift from Cuba to Florida commenced. ${ }^{192}$ Within six weeks more than 100,000 Cubans flooded southern Florida. ${ }^{193}$ Many of the Cubans who were interviewed as they stepped ashore explained that they were coming to the United States because food was scarce in Cuba or they thought they could earn more in this country. ${ }^{194}$ Most were soon claiming that they had fled the oppression of the Castro regime; the INS treated them as they had previous influxes of Cubans, that is, as refugees. ${ }^{195}$

The irony of rejecting Haitians who allegedly arrived for economic reasons, while accepting Cubans who initially asserted they came for economic reasons, was not lost on either the U.S. media or the public. The vacillations and chaos in the handling of the Cuban crisis by the Carter Administration received most of the media's attention, but local Miami and some national media noted the blatant inconsistencies between the treatment of the Cubans and Haitians. ${ }^{196}$ Cubans were quickly processed and released, classified as asylum applicants, while the Haitians were still classified as being in exclusion proceedings. Some of the Cubans were given cash gifts by the U.S. authorities, while the Haitians were detained in jails. ${ }^{197}$

Clearly, the U.S. Government could not at the same time welcome self-proclaimed economic refugees from Cuba while rejecting Haitians for allegedly being no more than economic refugees. Although some of the arriving Cubans are also black, such contradictory treatment would be indicative of racial and ideological bias.

Haitian advocates were quick to advance charges of discriminatory treatment. Marches were staged in Miami, New York, Washington, and other cities. Hunger

191. Refugee Act of 1980, Pub. L. No. 96-212, 94 Stat. 102 (amending the INA, ch. 477, 66 Stat. 163, codified as amended at 8 U.S.C. $\$ \S 1101.1546$ (1976 \& Supp. 1981)).

192. See supra note 64 .

193. Interview with Ron Copeland, U.S. Dept. of State, Office of Refugees (Jan. 19, 1983).

194. Id.

195. Id.

196. See, e.g., Brimmer, The Haitian Exception, Wash. Post, May 8, 1980, at A19, col. 2; The Other Refugees, Wall St. J., Apr. 28, 1980, at 24, col. 1; Giving Refuge-And Taking It, N.Y. Times, Apr. 16, 1980, at A26, col. 1; Why Treat Haitians as Second-Class Refugees.? Newsday, Apr. 16, 1980 (Nassan ed.).

197. Personal interviews with numerous involved parties from Miami and Washington, D.C. See also Caribbean Migration, supra note 5, at 223-35 (statement of David Crosland, Acting Commissioner, INS); transcript of Final Hearing at 266, Louis v. Meissner, No. 81-1260 Civ.-EPS (S.D. Fla. Mar. 15, 1982) (testimony of Monsignor Walsh). 
strikes, letter-writing campaigns, and visits with members of Congress and highranking Carter Administration officials were conducted. ${ }^{198}$ The Congressional Black Caucus organized a campaign of letters of protest to President Carter. These letters were signed by the members of the Congressional Black Caucus, numerous other members of Congress, civil rights leaders, and union officials. ${ }^{199}$ The Senate Judiciary Committee held hearings on the Cuban-Haitian crisis and grilled Victor Palmieri, Carter's Ambassador for Refugee Affairs, on the administration's double standard. ${ }^{200}$

In general, press coverage was favorable to the Haitians. Lead editorials in the New York Times, the Washington Post, and other major newspapers asked the administration to grant the Haitians refugee status. ${ }^{201}$ Still, there was no observable change in the government's position; the administration made no move to legalize the status of the boat people.

In May and again in June, 1980, President Carter announced and outlined the administration's new Cuban-Haitian policy. In brief, he promised equal treatment and a temporary legal status for both Cubans and Haitians, but refugee status for neither. Instead he suggested a singular status, Cuban-Haitian Entrant, to be created by special congressional legislation. ${ }^{202}$ The administration justified this ad hoc approach by condemning the past discriminatory treatment and explicitly stating that refugee status for either group would undermine the meaning and intent of the Refugee Act of 1980. ${ }^{203}$ Off the record it was readily admitted that political realities demanded acceptance of the Cubans. ${ }^{204}$ Meanwhile, the Attorney General granted the Cuban and Haitian entrants a six-month renewable parole. ${ }^{205}$ The Cuban-Haitian Entrant Program was designed only for those migrants who arrived before October 10, 1980. Castro conveniently cut off the flow of Cubans, but Haitians continued to arrive.

At first, the INS took no action on the new Haitian arrivals. They were processed at Krome North, a detention facility outside Miami, and released if

198. See, e.g., Grimm \& Tasker, 1,000 March to Urge Asylum for Haitians, Miami Herald, Apr. 20, 1980; Grimm \& Oglesby, Dade Leaders to Press Carter on Haitian Asylum, Miami Herald, Apr. 17, 1980; Grimm \& Bartlett, Political Heavyweights Bring Bout Here, Miami Herald, Mar. 9, 1980 at 7B, col. 1; Resolution of the Mayor and City Council of Atlanta (May 8, 1980); News from the UAW, Stepp Protests Government Treatment of Haitian "Boat People" (May 1, 1980); National Black Hispanic Democratic Coalition, Press Release (Apr. 16, 1980); Letters to Pres. Carter from Calif. State Rep. Maxine Waters (Feb. 11, 1980), Tex. State Reps. Al Edwards (May 12, 1980) and Paul Elizondo (Apr. 28, 1980), migrant and farmworkers union leaders Antonio Orendain, Lupe Sanchez, and Juan Velasquez (Jan. 23, 1980), National Hispanic Housing Coalition (May 7, 1980), National Urban League President Vernon Jordan (Apr. 17, 1980), National Office for Black Catholics (Apr. 17, 1980), Lutheran Church in America (Apr. 24, 1980), American Jewish Committee (Apr. 16, 1980), National Conference of Catholic Bishops (Apr. 18, 1980), and Progressive Amateur Boxing Association (Apr. 18, 1980); Letter from Rep. Mickey Leland to Baltasar Luna, President, National Image, Inc. (Apr. 24, 1980).

199. See, e.g., Letter from Rep. Shirley Chisholm, Sen. Dick Stone \& Sen. Patrick Moynihan, et al. to Pres. Carter, Apr. 2, 1980.

200. Sawyer, Refugee Policy Draws Fire in Hearing, Wash. Post, May 12, 1980, at A6, col. 1.

201. See supra note 196.

202. The White House, New Cuban-Haitian Plan, Fact Sheet No. 114, July 1980, at 10-11.

203. See Briefing by Victor Palmieri, U.S. Coordinator for Refugee Affairs (June 20, 1980).

204. Babcock, Open Ams, Wary Eyes Greet Newest Refugees, Wash. Post, May 11, 1980, at Al2, col. 1.

205. The White House, supre note 202, at 10. 
sponsors could be found for them, pending exclusion hearings. By February, 1981, a backlog of over 11,000 cases had accumulated. ${ }^{206}$ The INS again began to deal with Haitian asylum claims. Their efforts seemed remarkably reminiscent of the earlier Haitian Program.

Beginning June 1 mass hearings commenced. UP to forty Haitians at a time were led handcuffed into INS hearing rooms. ${ }^{207}$ On at least one occasion the door to the hearing room was locked, and when an attorney from the Haitian Refugee Center sought entrance, he was informed that the judge did not want him in the courtroom. ${ }^{208}$

Between June 1 and June 5, 1981, exclusion hearings were conducted for 136 Haitians. Ninety-six were ordered excluded and deported; eleven were actually deported on June 4, and eighty-five were about to be deported on June 9, when a stay order was issued because of a suit filed by Haitian Refugee Center, Inc. ${ }^{209}$ The suit requested cancellation of the final deportation orders, claiming that the INS violated petitioners' rights to a "fair exclusionary hearing and to fair proceedings, and to consult with counsel." 210

The government contended that the Haitians had knowingly waived their rights to an attorney, had turned aside political asylum forms, and had indicated that they did not want an appeal.211 After hearing testimony the government agreed to reprocess the cases, ${ }^{212}$ but Haitian advocates nevertheless continued to maintain that the INS procedures were unconstitutional. Until August 1981, the INS regularly released Haitians pending their exclusion hearings and adjudication of asylum claims. ${ }^{213}$ Sometime between the spring and summer of 1981 , the INS changed its policy of regularly releasing Haitians to a policy of detention without parole, with a limited humanitarian exception. ${ }^{214}$ Because the Krome Processing Center had become overcrowded, the INS began to move Haitians to other centers throughout the United States: Lake Placid, New York; Brooklyn, New York; Otisville, New York; Morgantown, West Virginia; Lexington, Kentucky; Big Springs, Texas; and Fort Allen, Puerto Rico. Because these dispersed sites were far from both attorneys experienced in immigration hearings and Haitian communities which could monitor INS activities, Haitian advocates feared another speedup program in which the abrogation of Haitians' rights could easily occur. In September 1981, the United States District Court for the Southern District of Florida

206. Task Force on Immigration and Refugee Policy, Issue Paper-Subject: What Policy Should the United States Adopt with Regard to Foreign Persons Who Enter South Florida Without Visas? 3 (June 26, 1981)(memorandum to Pres. Reagan from task force established by him Mar. 6, 1981) [hereinafter cited as Immigration Task Force].

207. Matera, Haitians: Latins Fare Better, Miami News, June 24, 1981, at 5A.

208. Pear, Haitian Deportations Start; U.S. Orders Open Hearings, N.Y. Times, June 6, 1981, at A7, col. 1.

209. Louis v. Meissner, No. 81-1260-CIV-EPS (S.D. Flà. 1981).

210. Id. at 2 .

211. Judge Swamped with Haitian Hate Mail, Miami Herald, June 24, 1981, at B2, col. 1; Matera, supra note 207 , at $5 \mathrm{~A}$.

212. Respondents' motion and supporting memorandum to vacate petitioners' final orders of exclusion and to remand to INS, Jean v. Meissner, No. 81-1260-CIV-ALH (S.D. Fla. July 8, 1981).

213. Plaintiff's post-trial brief and proposed findings of fact and conclusions of law at 8, Louis v. Nelson, No. 81-1260-CIV.EPS (S.D. Fla. May 6, 1982).

214. Id. 
agreed and enjoined any exclusion proceedings for Haitians anywhere in the United States until adequate legal representation could be assured. ${ }^{215}$ Exclusion hearings could proceed for those Haitians represented by pro bono counsel through the Haitian Refugee Volunteer Lawyer Task Force of the Dade County Bar Association, but the injunction prohibited "entry of a final, non-appealable order of exclusion against them without prior notice being given to the court."216

In October 1981, the Reagan Administration began using a U.S. Coast Guard cutter to intercept boats found sailing in the straits between Haiti and the Bahamas which were suspected of transporting Haitians to the United States. ${ }^{217}$ If such evidence was discovered, the boats and their passengers were to be towed back to Haiti. Refugee claims were to be adjudicated on board by a team consisting of State Department members, an INS representative, a Creole interpreter, and possibly a representative from the United Nations High Commission for Refugees.

Because under this system the adjudication of claims is outside U.S. territory, the administration believes that the provisions of the Immigration and Nationality Act do not apply. ${ }^{218}$ Nevertheless, the administration is concerned that southeast Asian nations might consider the actions hypocritical. ${ }^{219}$ In the wake of the massive exodus from Vietnam and Cambodia, the United States has prevailed upon southeast Asian nations not to turn boat people back to their homelands. The administration reasons, however, that Haitians can "return to their homeland without fear of reprisal," 220 and that the cases, therefore, are not comparable.

By July 1982, the U.S. Coast Guard cutter had found four boats apparently transporting Haitians to the United States. ${ }^{221}$ While a few smugglers have been caught, detected arrivals have dropped dramatically. Fewer than 120 Haitians arrived between January and October of 1982 , compared to nearly 8,000 for the same time period in 1981.222 Not all arrivals are detected, however, and it is estimated that between 75 and 200 Haitians still arrive undetected each week. ${ }^{223}$ Because they are undetected, public reaction is minimal. On the other hand, boatloads of Haitians attempting to reach the United States have been battered by storms and wrecked just off the shore of southern Florida on two occasions. In October 1981, the bodies of thirty-three Haitians washed ashore. ${ }^{224}$ In March 1982, twenty-one met the same fate. ${ }^{225}$ The tragedies provoked a humanitarian

215. Louis v. Meissner, No. 81-1260 Civ.-EPS, slip op. at 4 (S.D. Fla. Feb. 24, 1982) (memorandum opinion and order granting defendant's motion to dismiss in part).

216. Id.

217. Fuller, Memorandum for the Cabinet: Immigration Issues (July 10, 1981) (Office of Cabinet Administration, The White House).

218. Immigration Task Force, supra note 206, at 5.

219. Id. at 6.

220. Id. See also statement of Ambassador Preeg, U.S. Ambassador to Haiti, at the Wingspread Symposium on Haiti: Present State and Future Prospects, in Racine, Wis. (Sept. 23-26, 1982).

221. Telephone interiew with Ralph Thomas, consultant to the INS Commissioner (Jan. 3, 1983).

222. Letter from Doris Meissner, Acting Executive Associate Commissioner, INS (Dec. 7, 1982).

223. Clary \& Starita, Haitians Still Amiving, Panel Told, Miami Herald, Feb. 21, 1982, at 1D, col. 1

224. Wolin, Mass Funeral Service Planned for Haitians Who Drowned, Miami Herald, Apr. 3, 1982, at 4A, col. 6 .

225. Gyllenhaal \& Early, Bahamian Owned Ship, Haitians Say, Miami Herald, Apr. 2, 1982. 
outcry, ${ }^{226}$ but no change in policy. The INS took into detention five of the six survivors of the March sinking. ${ }^{227}$

Meanwhile, on February 24, 1982, the court dismissed all the issues in the Haitian Refugee Center case except those concerned directly with detention. It reasoned that administrative relief had not been exhausted since the asylum claims and exclusion proceedings had been taken to the court before reaching the Board of Immigration Appeals. ${ }^{228}$

The court did retain jurisdiction over issues relating to the detention of Haitians, specifically whether the detention policy had been changed in violation of the rulemaking requirements of the APA, ${ }^{229}$ whether it was "currently being applied in a discriminatory fashion," and whether it denied Haitians first amendment rights of access to persons not in detention. ${ }^{230}$

Meanwhile the Haitian advocates initiated a similar case in New York's southern district court on behalf of eight Haitians originally detained at the Krome Processing Center and later transferred to an immigration detention facility in Brooklyn, New York. This case specifically challenged the legality of INS's detention of Haitians in spite of requests for parole. On March 5, 1982, the court ruled that the detention policy violated both U.S. law and the UN Protocol by "discriminating" against petitioners because of their race or national origin. ${ }^{231}$ The INS District Director's denial of parole to Haitians was "motivated by a desire to discriminate against Haitians"232 and "demonstrate[d] a gross maldistribution of releases." 233 The letters denying Haitians' requests for parole were found to be "completely devoid of rational, legitimate bases."234 Furthermore, the District Director had authored a memo "which indicated a predetermination that none of the Haitians could deserve asylum." 235 In an opinion dated April 5, 1982, the court ordered the INS to parole all fifty-three class members concluding that "after 10 months of unlawful confinement in a harsh environment, justice demands swift remedial action." 236

On June 25, 1982, the Court of Appeals for the Second Circuit, however, reversed and remanded the decision. ${ }^{237}$ The appellate court found that the INS District Director's denial of parole fell within his discretionary power even if the decisions were 'based on generalizations that were 'casual' or 'inaccurate.' ",238 Furthermore, the Second Circuit found that "the Protocol affords the petitioners

226. See, e.g., Detention Must End, Miami Herald, Apr. 3, 1982, at 26A, col. 1.

227. Latest Haitian Deaths Bare U.S. Policy Flaws, Miami News, Apr. 2, 1982, at 12A, col. 1.

228. Id. at 10 .

229. 5 U.S.C. $\$ 553$ (1976).

230. Louis v. Meissner, No. 81-1260 Civ.-EPS (S.D. Fla. Feb. 24, 1982) (memorandum opinion and order granting defendant's motion to dismiss in part).

231. Vigile v. Sava, 535 F. Supp. 1002 (S.D.N.Y. 1980), rev'd, 684 F.2d 204 (2d Cir. 1982).

232. Id. at 1016 .

233. Id.

234. Id. at 1017 .

235. Id. (emphasis in original).

236. Bertrand v. Sava, 535 F. Supp. 1020 (S.D.N.Y. 1982), rev'd, 684 F.2d 204 (2d Cir. 1982).

237. Bertrand v. Sava, 684 F.2d 204 (1982).

238. Id. at 213-14. 
no rights beyond those they have under domestic law."'239

On June 29, 1982, the Organization of American States' Inter-American Human Rights Commission commenced an investigation of human rights violations in the detention of Haitians in the United States. ${ }^{240}$ On that same day, Judge Spellman of the United States District Court for the Southern District of Florida ordered the release of the more than 1,900 Hatians from detention facilities throughout the United States. ${ }^{241}$ Judge Spellman found that the regulations allowing detention of newly arriving Haitians were invalid as they were not promulgated in accordance with the APA. ${ }^{242}$ While the court also found it "undisputed that Haitians are impacted to a greater degree by the new detention policy than aliens of any other nationality," 243 plaintiffs had "failed to prove by a preponderance of the evidence that they were incarcerated because of their race and/or national origin."'244

An assistant U.S. Attorney claimed that the ruling might result in a massive influx of Haitians to Florida, ${ }^{245}$ and the Reagan Administration appealed the decision to the 11 th Circuit in Atlanta. ${ }^{246}$ Judge Spellman then ruled that aliens who arrived after his order could be detained by the INS. ${ }^{247}$

The Haitians were released under the sponsorship of individuals or voluntary agencies. The American Bar Association and the Dade County Bar Association were called upon to provide pro bono services for the Haitians' exclusion hearings. 248

In July 1981, the Reagan Administration announced its immigration proposals $^{249}$ which were finally introduced in Congress in October 1981.250 The problem of the Haitian boat people was one of the main concerns addressed in the proposals, ${ }^{251}$ although there was no indication of sympathy for the Haitians'

239. Id. at 219 .

240. Chardy \& Silva, OAS Probes Alien Rights in U.S. Camps, Miami Herald, June 29, 1982, at $1 \mathrm{~B}$.

241. Payne \& York, Judge's Order Frees all Haitian Refugees, Miami News, June 29, 1982, at 1 A.

242. Louis v. Nelson, No. 81-1260 Civ.-EPS, slip op. at 31-32 (S.D. Fla. June 29, 1982) (memorandum opinion).

243. Id. at 37 .

244. Id. at 42 .

On April 12, 1983 the 11th Circuit Court of Appeals reversed Judge Spellman's findings on discrimination stating that the Government's detention policy evidenced "a stark pattern of discrimination" against Haitians. The discrimination occurred, the court said, because the year-long policy was applied "solely, and uniformly, to Haitians." The appellate court remanded the case to Judge Spellman and directed that he: (1) issue an injunction forbidding discriminatory enforcement of a new policy; (2) continue the parole of the 1,771 Haitians freed last year, (3) require the INS to keep records adequate to satisfy the court that the policy is being enforced without discrimination, (4) ensure lawyers' right of access to aliens held in detention and the aliens' right to request asylum, (5) take any steps necessary to "ensure that all aliens, regardless of their nationality or origin, are accorded equal treatment." Louis v. Nelson, No. 82-5772, at 113 (11th Cir. Apr. 12, 1983).

245. Miami Herald, June 30, 1982.

246. Klement \& Martinez, U.S. Fights Freeing Haitian Aliens, Miami Herald, July 1, 1982, at 1C.

247. Klement, Judge Okays Detention of New Aliens, Miami Herald, July 3, 1982, at 1 A.

248. Gyllenhaal \& Klement, U.S. Seeks a Review of Ruling, Miami Herald, June 30, 1982.

249. Fuller, supra note 217.

250. H.R. 4832, 97th Cong., 1st Sess., (introduced simultaneously as S. 1765, with text reprinted at 127 Cong. Rec. S11,993 (daily ed. Oct. 22, 1981)). See particularly Title IV-The Fair and Expeditious Appeal, Asylum and Exclusion Act of 1981.

251. Immigration Reform and Control Act of 1982: Joint Hearings on H.R. 5872 and S. 2222 Before the Subcomm. 
claims for political asylum. Rather, the proposed legislation attempts to legitimize what the courts have found illegitimate under current law: limitation of the rights of aliens claiming asylum, restriction of judicial review of asylum processing, and interception of Haitians in international waters for the purpose of returning them to Haiti before they come within U.S. jurisdiction. ${ }^{252}$

The administration's proposed legislation (1) bars applications by aliens who come into the United States in transit without visas or who enter without inspection, a qualification which applies perfectly to the boat people; (2) limits the participation of counsel during asylum interviews; (3) bars administrative appeals and review except for certification by the Commissioner or Attorney General; (4) bars motions to reopen except upon a clear showing of changed circumstances; and (5) allows judicial review of a denial only in the context of a review of a final order of deportation or exclusion. ${ }^{253}$

The Department of Justice requested these changes from Congress because, "[U]nder the present system, the appeal process is abused by applicants with frivolous claims." 254 Limiting participation of counsel would "prevent the asylum interview from deteriorating into an adversarial proceeding." 255 No independent judicial review of an asylum application would be allowed in order to "prevent abuse of the asylum process as a method of preventing deportation."256 Final orders of exclusion or deportation would be subject to appeal under a writ of habeas corpus to the court of appeals. ${ }^{257}$ Review, however, would be limited to the record developed during the exclusion or deportation hearing. ${ }^{258}$ The act would, moreover, bar any review of an asylum claim during an exclusion or deportation hearing. ${ }^{259}$ Thus, the record before the court of appeals would contain nothing to review concerning factual or discretionary decisions by asylum officers. $^{260}$

A Department of Justice memorandum claims that the suggested procedures are consistent with articles 31 and 32 of the UN Protocol. ${ }^{261}$ Article 31 indicates, however, that regardless of legal or illegal entry, aliens still have a right to claim asylum. ${ }^{262}$ Moreover, the memorandum ignores article 33, which bars a state from

on Immigration, Refugees $\mathcal{G}$ Int'l Law of the House Comm. of the Judiciary and the Subcomm. on Immigration and Refugee Policy of the Senate Comm. of the Judiciary, 97th Cong., 2d Sess. 360 (1982) (statement of Rep. Shirley Chisholm).

252. Id.

253. D. Crosland, Draft Asylum Bill (Department of Justice memorandum from David Crosland, General Counsel, to Doris M. Meissner, Acting Commissioner, INS). See Kurzban, Restructuring the Asylum Pracess, 19 SAN Diego L. Rev. 191 (1981).

254. D. Crosland, supra note 253 , at 2.

255. Id.

256. Id. at 4 .

257. H.R. 4832 , sec. $403, \S 208$ (d).

258. Institute for Public Representation, Georgetown Law School, Memorandum Reviewing Title IV-The Fair and Expeditious Appeal, Asylum and Exclusion Act of 1981, 63 (Nov. 1981)(unpublished memorandum).

259. Id.

260. Id.

261. D. Crosland, supra note 253 , at 1.

262. Protocol, supra note 15 , at art. 31 . 
returning an alien to a country where he would be persecuted. (Of course, the administration does not concede that the typical Haitian would be persecuted.)

In March 1982, Senator Simpson and Congressman Mazzoli, respectively the Chairmen of the Senate and House Immigration Subcommittees, jointly introduced their own immigration proposals, S. 2222 and H.R. $4832 .{ }^{263}$ Following hearings on the bills and markup in the respective subcommittees and full judiciary committees, the Senate passed an amended version in August 1982. After the November 1982 elections, the full House debated the bill in the waning days of the lame duck session.

The congressional legislation proposed by Simpson and Mazzoli would change principally three areas of asylum law by providing for: (1) a summary exclusion procedure for aliens who arrived without documentation; (2) the creation of special adjudication procedures for asylum claims; and (3) the reduction in scope of judicial review available for asylum decisions. ${ }^{264}$ Under both bills, aliens would be summarily excluded by the INS if they did not present the documentation required for entry, had no legal basis for entry, and did not indicate an intention to apply for asylum. ${ }^{265}$ The House version indicated that an alien would have to be informed of his right to have his case redetermined by an administrative law judge while the Senate version provided for no such review. ${ }^{266}$

The Senate and House versions of the bill each called for establishment of a system of administrative law judges for hearing asylum claims and a U.S. Immigration Board (USIB) for appeals of all final immigration determinations except summary exclusion procedures. ${ }^{267}$

Under the Senate bill, the USIB and the administrative law judges would be appointed by the Attorney General, while in the House version the President would appoint the USIB and the chairman of the USIB would appoint the administrative law judges. ${ }^{268}$

The Senate bill explicitly disallowed judicial review of asylum claims, although the constitutional right of habeas corpus remained. ${ }^{269}$ The House version provided that deportation, exclusion, and asylum decisions, following review by the USIB, may be reviewed as a matter of right in a federal court of appeals. ${ }^{270}$

While the House Report stated that "administrative shortcomings, not judicial interference, has [sic] caused the enormous backlog in asylum cases," 271 the House bill nevertheless provided that there is to be no judicial review of any aspect of the asylum process until a final order of exclusion or deportation is entered by the USIB. ${ }^{272}$ The House Committee, moreover, authorized multiple party habeas

263. S. 2222, 97th Cong., 2d Sess. (1982). See 128 Cong. Rec. S2215, (daily ed. Mar. 17, 1982).

264. National Immigration, Refugee \& Citizenship Forum, Forum Informational Bulletin 10-12, (Sept. 30, 1982).

265. Id. at 10 .

266. Id. at 10-11, asylum summary table.

267. Id. at 11 .

268. Id.

269. Id. at asylum summary table.

270. Id. at 11 .

271. H.R. REP. No. 890, 97th Cong., 2d Sess. 53 (1982).

272. Id. at 50 . 
actions when such actions would promote judicial efficiency and the ends of justice. ${ }^{273}$ The committee members were particularly concerned with the long term detention of Haitians, and included a "speedy trial" rule similar to that established under the federal speedy trial statute for criminal offenses. ${ }^{274}$

\section{$\mathrm{V}$ \\ CONCLUSION}

Since the arrival of the first Haitian boat people, the various Democratic and Republican administrations have consistently deemed Haitians to be undeserving of-refugee status. Haitian advocates have focused their challenges on procedural irregularities and the discriminatory treatment accorded the boat people by the INS. The challenges have apparently done nothing to alter the views of the INS or the administration. Under court pressure, policies, and less frequently practices, have been improved. Yet, whenever possible, at the lifting of a court order or the change of an administration, policy and practice have reverted to the former standards.

The courts have been a principal battleground of the Haitian refugee dispute, but they have not resolved it. Rather, they have issued ambiguous and vacillating opinions. In May 1982, the Fifth Circuit modified and affirmed the Haitian Refugee Center decision. ${ }^{275}$ The court found that aliens have a fragile, but protected, right to petition for asylum. ${ }^{276}$ Under the Haitian Program, it "strained credulity to assert that these plaintiffs were given a hearing on their asylum claims at a meaningful time and in a meaningful manner." 277 In short, the Haitians were entitled under the fifth amendment to more due process than they received. ${ }^{278}$

At the same time, the circuit court found it unnecessary to rule on the appellees' contention that the Haitians were victims of unlawful discrimination on the basis of national origin. Moreover, the court noted that it did not approve of the sweeping conclusions of the district court. ${ }^{279}$ Nevertheless, it agreed that the district court's admission of evidence on political conditions in Haiti was proper for corroborating claims that the accelerated hearings did not afford Haitians a fair opportunity to present all such evidence, but improper in implying that the Haitians' claims of fear of persecution were actually merited rather than just not frivolous. ${ }^{280}$

The issues presented by the Haitian refugee crises are not ones which will be settled easily or quickly. They strike at the heart of the inconsistency between U.S. asylum law and practice. The general issues brought to light by the Haitian refugee crises are:

273. Id. at 51 .

274. Id. at 53 .

275. Haitian Refugee Center v. Smith, 676 F.2d 1032 (5th Cir. 1982).

276. Id. at 1039 .

277. Id. at 1040 .

278. Id. at 1040-41

279. Id. at 1041 .

280. Id. at 1042 . 
(1) U.S. refugee and asylum policy is based on humanitarian and nondiscriminatory principles;

(2) In practice, it is used extensively as a tool of foreign policy to favor those migrants fleeing Communist regimes and against those fleeing rightist regimes;

(3) The ideological position or world view of those who make the policy and those who implement it allows them to believe that they are fair and nondiscriminatory in such behavior, since their reasoning is that totalitarian regimes are ipso facto repressive while authoritarian ones are far more selectively repressive.

In the specific case of the Haitians, the evidence indicates that many of the Haitians are fleeing a persecution which results from a regime best described as "lawless" and a "kleptocracy." Either the former Haitian officials are lying about the Haitian Government's policies of persecuting returnees, or boat people are ipso facto "refugees," regardless of their motivations for leaving.

Although the courts have not always supported the contentions of the Haitians seeking asylum in the United States, they have frequently noted the discrepancy between principle and practice. The independent power of the courts has made it virtually impossible to deport the Haitian boat people back to Haiti for the past four years. The administration continues to appeal their court losses. Most recently, the Reagan Adminsitration and the Chairmen of the Senate and House Immigration Subcommittees have proposed changing the laws. To resolve the battle, the administration must either convince the courts that those fleeing rightist persecution and corruption do not have a "well-founded fear of persecution," change asylum law to reflect foreign policy goals, or change foreign policy goals. Meanwhile, southern Florida is left to struggle with a potentially explosive problem.

The number of Haitians is minuscule compared to the number of Indochinese throughout the country, or even the number of Cubans in Miami, but the Haitian case is a test case of U.S. asylum policy. Will foreign policy and covert racist concerns continue to predominate U.S. asylum policy, or will broad humanitarian concerns overcome the recent historical tradition? Undoubtedly, the question will not easily be resolved. 